\title{
Quality of Indonesia's Domestic Institutions and Export Performance in the Era of Global Value Chains
}

\section{Arief Bustaman ( $\nabla$ arief.bustaman@unpad.ac.id )}

Padjadjaran University: Universitas Padjadjaran https://orcid.org/0000-0002-4086-9216

\section{Rina Indiastuti}

Padjadjaran University: Universitas Padjadjaran

\section{B Budiono}

Padjadjaran University: Universitas Padjadjaran

\section{Titik Anas}

Padjadjaran University: Universitas Padjadjaran

\section{Research}

Keywords: Institutional quality, export performance, global value chain, Indonesia

Posted Date: July 12th, 2021

DOI: https://doi.org/10.21203/rs.3.rs-696535/v1

License: @ (i) This work is licensed under a Creative Commons Attribution 4.0 International License. Read Full License 


\title{
Quality of Indonesia's Domestic Institutions and Export Performance in the Era of Global Value Chains
}

\author{
Arief Bustaman, Rina Indiastuti, B. Budiono, Titik Anas \\ Dept. of Economics, Padjadjaran University, Indonesia
}

Correspondence: Arief Bustaman (arief.bustaman@unpad.ac.id)

\begin{abstract}
The focus of this research is on analysing the effects of institutional quality and trade agreements on Indonesia bilateral trade in four commodity groups in the era of global value chains (GVSs). Employing a panel data gravity model of Indonesian export of four commodities to Indonesia's 18 trading partners from 2000 to 2018, and estimating the Feasible Generalized Least Squares (FGLS) and the Poisson Pseudo Maximum Likelihood Method (PPML), the results of this study find that institutional quality plays a different role in explaining Indonesia's export performance of those four commodities, despite the fact that institutions contribute positively. Regarding raw material and capital goods export, trading partner institutions are significant factors for Indonesian export of the two commodities. On two commodities that are relevant to Indonesia participation in the global value chain, exported intermediates and consumer goods, we find that although both domestic institutions and trading partner institutions are significant to Indonesian export, but we argue that domestic institutions contribute more. This study also reveals that through tariff reductions, Indonesian trade agreements are significant regarding export of intermediate and consumer goods, but less so for raw material and capital goods.
\end{abstract}

Keywords: Institutional quality, export performance, global value chain, Indonesia

\section{Introduction}

For countries that adopt an open economic system, foreign trade, especially exports, has a very important role in driving national economic growth. International trade has played an important role in the process of economic development in many developing countries. This is because international trade, especially exports, is a significant source of foreign exchange, can stimulate domestic production, and can create jobs. Palley (2012) notes that the export-led growth strategy was applied in several countries in the Asian region such as South Korea, Taiwan, Hong Kong, and Singapore, which at the time were developing countries in the 1970-1980 era; and they were then followed by Malaysia, Thailand, and Indonesia in the 1980 s to 1990 s. Islam (1998) shows that there is a causal relationship between exports and economic growth in the economies of India, Indonesia, Korea, and Thailand. Furthermore, the export-led growth strategy that emerged in the 1970s replaced the import substitution strategy, which has led to the emergence of new industrial countries such as South Korea, Taiwan, Hong Kong, China, and Mexico. Myint (1979) explains that the exportled growth mechanism can operate through three channels. Firstly, expanding exports will 
increase direct profits from trade and facilitate economic growth. Secondly, exports contribute to economic development, especially through the provision of foreign exchange for developing countries for the purchase of capital goods and other inputs from abroad. Thirdly, international trade and expansion of exports, indirectly, have an impact on productivity efficiency in the country as a consequence of economic openness, facilitating the spread of new needs and activities, new technology, and new economic organisation.

In the case of Indonesia, exports have long been one of the targets for boosting its economic growth. The export sector has been playing an important role in the Indonesian economy from the mid-1970s to the present. From the 1970s to the early 1980s, when world oil prices began to decline, oil and gas exports became a priority (Soesastro and Basri 2005). In response to the decline in world oil prices, the Indonesian government began to focus on manufacturing exports since the beginning of 1983. From 1983 to 1995, more than 24 economic reform packages were designed to increase investment, reduce trade barriers, increase efficiency, and strengthen the non-oil and gas export economy. This economic transformation enhanced Indonesia's economic performance, as demonstrated by an annual GDP growth of 6.3\% between 1985 and 1990 (Soesastro and Basri, 2005).

After 32 years of President Soeharto's reign (in office: 27th March 1968 - 21st May 1998 ) in the New Order era, economic reforms in the various eras of the next presidencies have continued with exports still being a policy priority and they have contributed significantly to the Indonesian economy. However, despite various economic reform programmes under different regimes, Indonesia's export value still shows a relatively poor performance. For example, in the last 3 decades it has always been consistently below that of Malaysia and Thailand (as the two exporting countries in the region of the Association of Southeast Asian Nations, ASEAN). The Graph 1, shows the export value of Indonesia and 3 major exporter countries in the ASEAN region, namely Malaysia, Thailand, and Vietnam (hereinafter referred to as the main ASEAN exporting countries). In the 1980s to 1993, Indonesia's export value surpassed that of Thailand, but was below that of Malaysia. From 1993 to 2016, Indonesia was below that of Malaysia and Thailand. Even since 2015, Vietnam's export value has surpassed that of Indonesia. 
Graph 1 Export Value of Selected ASEAN Countries in US\$ Source: www. wits.worldbank.org, authors' calculation



A number of empirical studies have pointed out the cause of stagnation, if not decline, Indonesia's export performance is not caused by uncompetitive exchange rates or higher labour costs, but is rather due to a decrease in foreign direct investment (Adams et al. 2006) and foreign trade policies that do not support export performance (Adams et al. 2006; Soesastro and Basri 2005). Furthermore, Athukorala (2006) also emphasised the slow pace of microeconomic reform after the 1997 crisis as one of the causes of Indonesia's poor export performance. Athukorala's argument is also supported by Molnar and Lesher (2008) who state that internal constraints and developments in the international market have hindered Indonesia's competitiveness, including the relationship to trade policies. Another study, by Wengel and Rodriguez (2006), examined Indonesian exports by Small and Medium Enterprises (SMEs), and found that the overly complicated regulations and decentralisation in Indonesia made the costs of setting up a business in Indonesia too burdensome for SMEs, and are among the highest in Asia. The various export-inhibiting problems mentioned above are better known in the economic literature as institutional factors. In addition, a recent study by Isnawangsih and Lu (2018) recommends the importance of Indonesia in improving regulatory quality to increase global value chain participation. Thus, it is imperative for Indonesia to have good domestic institutions if it wants to improve its export performance by shifting reliance from raw materials exports, which tend to have low prices, to goods of higher quality and high value. 
There are several institutions that publish data on the quality of institutions in various countries in the world. For example, Worldwide Governance Indicators (WGI) data published by the World Bank since 1996 can reflect the quality of institutions in political, legal and economic aspects in 215 countries. WGI measures institutional governance using 6 dimensions, namely Voice and Accountability, Political Stability and Absence of Violence/Terrorism, Government Effectiveness, Regulatory Quality, Rule of Law, and Control for Corruption. Other available data for institutional qualities are law, bureaucracy and democratic accountability that published by the PRS Group which provides data for 140 countries; and POLITY IV institutional data published by the Center for Systemic Peace. The following graph 2 illustrates the quality of institutions in Indonesia which is sourced from the Worldwide Governance Indicators (WGI).

\section{Graph 2 Six Dimensions of Institutions Quality in Indonesia Source: Worldwide Governance Indicators}



World Governance Indicators calculates the quality of institutions in 215 countries on a scale from the worst $(-2.5)$ to the best (2.5). From the graph above, it can be seen that during 2000 to 2017 , the majority of the quality of Indonesian institutions were in the poor category, as reflected by numbers below 0 . While the components that had positive numbers were only found in the last few years, namely on the voice and accountability since 2012 and the government effectiveness since 2017. However, throughout this period, all components showed significant improvement. For comparison, the following graph 3 shows the quality of institutions of four quality dimensions related to trade (i.e., Government Effectiveness, 
Regulatory Quality, Rule of Law, and Control for Corruption) in four exporting countries in the ASEAN region.

Graph 3 Four Dimensions of Institutions Quality related to international trade of main ASEAN exporter countries Source: Worldwide Governance Indicators

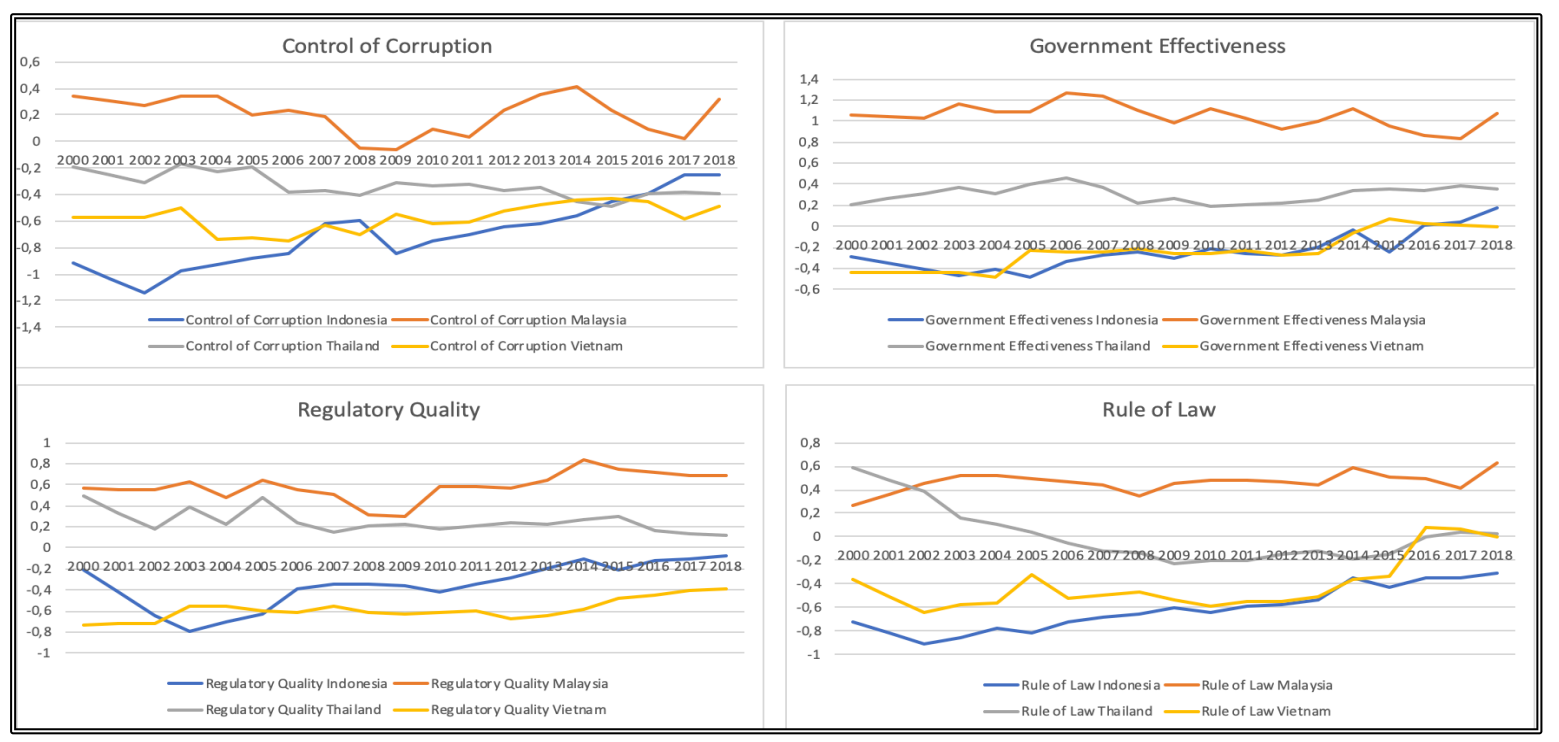

In the figure above, it can be seen that from 2000 to 2018, the quality of Indonesia's domestic institutions (shown by blue lines) was generally below Malaysia and Thailand (red and grey lines respectively). Meanwhile, compared to Vietnam (yellow lines), Indonesia only has advantages in terms of regulatory quality. These figures might explain why Indonesia is still struggling to increase its involvement in global value chain compare to other three countries in the ASEAN region.

Furthermore, in the era of trade liberalisation and the global value chain of the 2000s, Indonesia still struggles to increase its export performance, despite its involvement in a number of free trade agreements. One of Indonesia's efforts to improve export performance is by conducting international trade cooperation at various levels (bilateral, regional, and multilateral). Indonesia has committed to actively participate in efforts to integrate the world economy, especially through the trade sector, and Indonesia has joined in various free trade and cooperation agreements. Table 1 contains information on Indonesia's trade cooperation that has been in effect: 
Table 1 Indonesia Trade Agreement Cooperation in Effect Source: Asia Regional Integration Center (ARIC) Database, 2020

\begin{tabular}{clc}
\hline No & \multicolumn{1}{c}{ Agreements } & Effective Date \\
\hline 1 & ASEAN Free Trade Area (AFTA) & 1st January 1993 \\
2 & World Trade Organization (WTO) & 1st January 1995 \\
3 & ASEAN-China FTA & 1st January 2005 \\
4 & Indonesia-Japan EPA & 1st July 2008 \\
\hline 5 & ASEAN-Japan FTA & 1st December 2008 \\
6 & ASEAN-Korea FTA & 1st January 2010 \\
7 & ASEAN-India FTA & 1st October 2010 \\
8 & Preferential Tariff Arrangement-Group of & 25th August 2011 \\
& Eight Developing Countries & \\
9 & ASEAN-Australia-New Zealand FTA & 10th January 2012 \\
10 & Indonesia Pakistan PTA & 13th September 2013 \\
11 & Indonesia Australia CEPA & 5th July 2020 \\
\hline
\end{tabular}

Through the above trade agreements, Indonesia experienced tariff reduction on its export to trading partners. For example, in the context of ASEAN Free Trade Agreement, on average tariff reductions faced by Indonesia exports in the destination countries were not only quite significant but also considered to be low. The tariff imposed by neighbouring countries in ASEAN has been as low as below 1 percent since 2010, as depicted in the graph 4 below:

Graph 5 Average Import Tariffs on Indonesia Export to ASEAN countries Source: www.wits.worldbank.org, authors' calculation

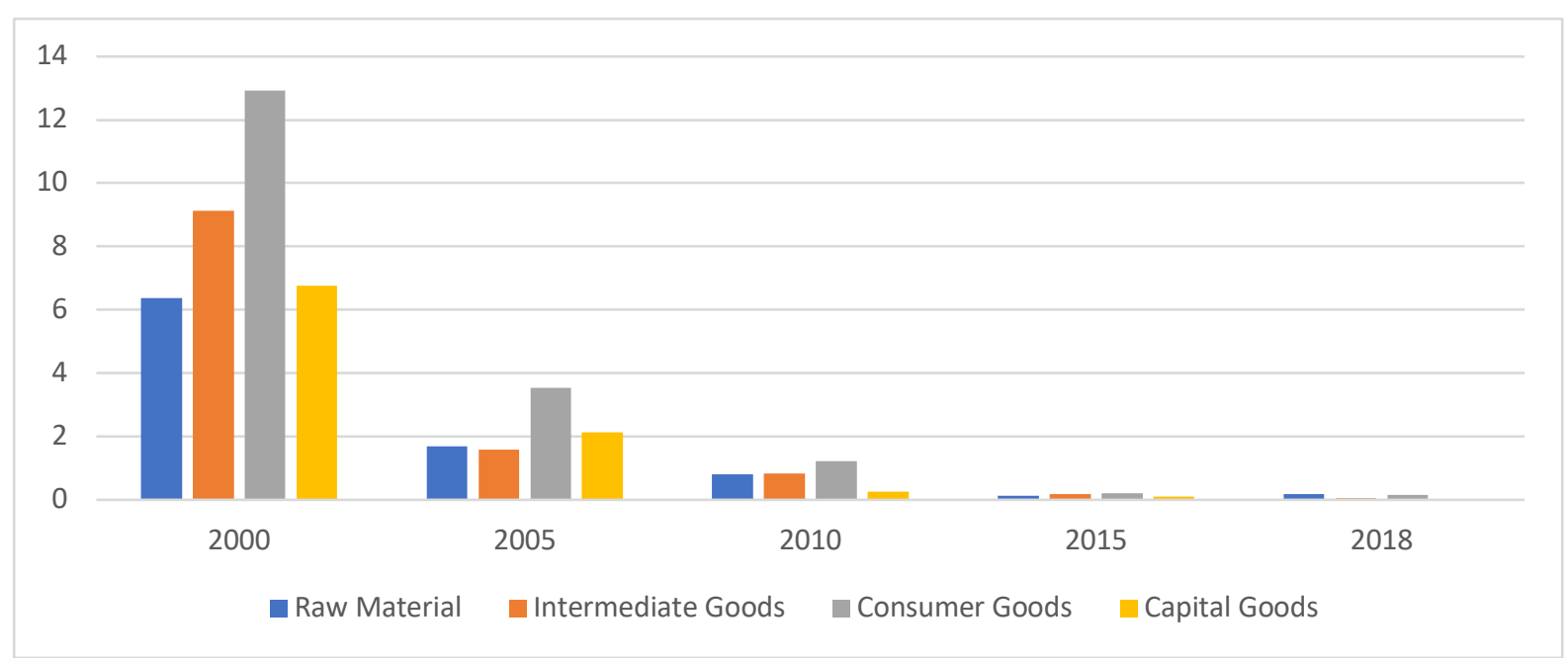

With the global production network phenomenon, it is imperative to consider the composition of commodities in analysing the trade performance of a country. In other words, determine if a country is trading more value-added products such as intermediate and capital or more consumer goods. In the context of the global value chain (GVC), one factor that needs to be considered is China's role as a manufacturing centre in the Asia region. As stated by Athukorala (2006), although growth in trade based on product fragmentation has become a 
global phenomenon, more important and rapid developments have occurred in the East and Southeast Asia region than in other regions of the world. Since the mid-2000s, many companies around the world have shifted their production processes to China with various inputs produced around the world. Graph 5 shows the main ASEAN exporting countries product compositions (left-side chart) and their intermediate goods export to China (rightside chart).

Graph 5 Selected ASEAN countries export compositions and their intermediate goods export to China Source: www.wits.worldbank.org, authors' calculation

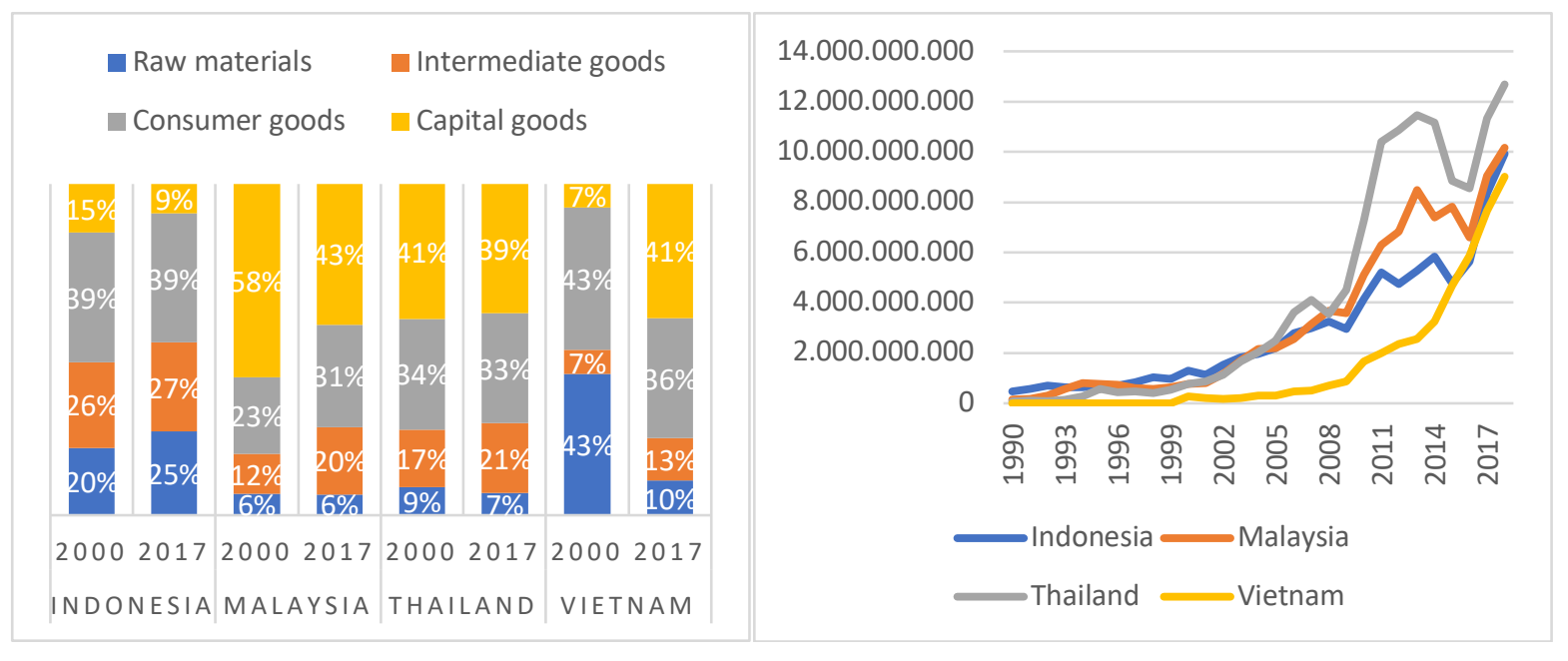

The data in the left chart of Graph 5 show that the structure of Indonesia's export products has remained relatively unchanged between 2000 and 2017, and this pattern is different from other countries. Indonesia's raw materials exports have actually experienced an increase in composition, while other countries have tended to stagnate or even decline and switch to other higher value-added commodities such as intermediate goods, consumer goods, or capital goods.

Furthermore, the right chart in Graph 5 depicts exports of intermediate goods to China, which is considered to be the world's factory for manufacturing and assembling. It can be seen that from 1990 to 2003, the export value of Indonesian intermediate goods to China was higher than the three countries. However, since 2004 Malaysia and Thailand have had better export performance in intermediate goods than Indonesia and since 2009 the export value gap has widened. What is even more worrying is that the trend of Vietnam's export value that exceeds Indonesia began to appear in 2016. Based on these data, it can be said that Indonesia's export performance is getting worse in the context of the global production network. This is also supported by empirical research conducted by Jongwanich (2010), who found that Indonesia, as a country that has not actively participated in the manufacturing product fragmentation process, is marked by the smallest growth in the share of manufactured exports among other countries in the ASEAN region. He specifically emphasizes the possibility of "Dutch Disease" phenomenon experienced by Indonesia, where exports of 
natural resource products dominate manufacturing exports. Furthermore, Jongwanich (2010) explains that among the 9 countries of the East Asia and Southeast Asia Region covered in his study, Indonesia has different export patterns and trends. For example, data shows that the other eight countries have a positive trend of increasing exports of products classified as machinery and transportation equipment (SITC 7) while Indonesia has not experienced a change in product composition, which is still textile and footwear products (SITC 8).

The importance for a country to export more varied, high-tech, and value-added goods is increasingly relevant in the era of globalisation and the global production network (Khandelwal, 2010; Sheng and Yang, 2016). The research of Funke and Ruhwedel (2001) shows that producing highly differentiated export goods provides a competitive advantage that allows a country to sell more products. The results obtained conclusively support the hypothesis that increasing export variation both horizontally and vertically may be as important as having competitiveness in the aspect of price. Fugazza (2005) explains that institutional factors play an important role in supporting export competitiveness and performance at a more advanced stage, i.e., exports commodities that are capital intensive or differentiated products or products of higher quality. Furthermore, Dollar and Kidder (2017) explain that countries with good institutional quality, for example, property rights and rule of law, will tend to have good performance in global value chains (GVCs).

Several studies show the importance of improving the quality of institutions as a companion to the policy of carrying out trade liberalisation (Dollar and Kraay 2003; Méon and Sekkat 2008). The argument of Jansen and Nordås (2004) may apply to the Indonesian case. In their study, they explained that the tariff reduction by trading partner countries was not sufficient to improve export performance, due to the high transaction costs faced by exporters. For example, the World Bank's World Development Indicators data for 2018 show that time to export, in term of hours, that are needed for documentary compliance in Indonesia is the longest (61.3 hours) compared to its peer exporter countries in ASEAN (i.e., Malaysia: 10 hours; Thailand: 11 hours; and Vietnam: 50 hours) as shown in Table 2.

Table 2 Trade facilitation in Time to Export Source: World Bank Development Indicators, 2018

\begin{tabular}{cccc|ccc}
\hline \multirow{2}{*}{ Countries } & \multicolumn{2}{c|}{\begin{tabular}{c} 
Time to export, documentary \\
\multicolumn{3}{c}{ compliance (hours) }
\end{tabular}} & \multicolumn{3}{c}{$\begin{array}{c}\text { Time to export, border } \\
\text { compliance (hours) }\end{array}$} \\
\cline { 2 - 7 } & $\mathbf{2 0 1 6}$ & $\mathbf{2 0 1 7}$ & $\mathbf{2 0 1 8}$ & $\mathbf{2 0 1 6}$ & $\mathbf{2 0 1 7}$ & $\mathbf{2 0 1 8}$ \\
\cline { 2 - 7 } China & 21.2 & 21.2 & 8.6 & 25.9 & 25.9 & 25.9 \\
India & 38.4 & 38.4 & 14.5 & 106.1 & 106.1 & 66.2 \\
Indonesia & 61.3 & 61.3 & 61.3 & 53.3 & 53.3 & 53.3 \\
Malaysia & 10 & 10 & 10 & 48 & 45 & 28 \\
Thailand & 11 & 11 & 11 & 51 & 51 & 44 \\
Vietnam & 50 & 50 & 50 & 58 & 55 & 55 \\
\hline
\end{tabular}


The literature on institutions that has been rapidly developed in recent years has highlighted the role of institutional quality in various aspects of a country's economic performance, including international trade. North (1991) states that institutions are boundaries designed by humans to regulate political, economic, and social interactions. Institutions can be in the form of informal restrictions (sanctions, taboos, customs, traditions, and codes of ethics), and formal rules (construction, law, property rights). The term institutional in international trade refers to various structures which affect economic output, such as in terms of contract implementation (contract enforcement), copyright rules, investor protection, political system, etc (Levchenko, 2007). Previous research shows that institutions are determinants of comparative advantage (Costinot 2009; Levchenko 2007; Nunn 2007). Furthermore, Nunn and Trefler (2014) explain that institutional factors become a source of comparative advantage that operate differently from traditional comparative sources, such as a country's endowment. Several studies have shown that, quantitatively, institutions have the same important role as traditional sources of comparative advantage.

The economic literature has categorised formal theory of international trade and institutions as part of the New Trade Theory (NTT) group. However, some researchers (e.g., Clarida and Findlay 1992; Kindleberger 1978) argue that the concept of thinking about institutions in international trade has appeared in classical International Trade Theory. Parrinello (2002) explains that Adam Smith, in his book An Inquiry into the Nature and Causes of the Wealth of Nations (published on 9th March 1776) has implicitly explained the role of institutional factors in international trade, with a concept termed as a "magistracy" system. Adam Smith explained that the government must (1) perform important tasks, including protecting community members from injustice and keeping one party from oppressing another party; (2) provide a framework for efficient private market operations; (3) provide law and order enforcement; (4) provide physical and social infrastructure for the State; and (5) provide contract enforcement by private agents. Smith noted that, without all of these factors, free trade and the market economy cannot function properly, written as follows:

"Commerce and manufactures can seldom flourish long in any state which does not enjoy a regular administration of justice, in which the people do not feel themselves secure in the possession of their property, in which the faith of contracts is not supported by law, and in which the authority of the state is not supposed to be regularly employed in enforcing the payment of debts from all those who are able to pay. Commerce and manufactures, in short, can seldom flourish in any state in which there is not a certain degree of confidence in the justice of government" (Smith 1776 p.387).

Furthermore, Parrinello (2002) describes the contribution of other classical economists, namely David Ricardo and Ohlin, to the concept of institutions and trade. David Ricardo, in his original book on Comparative Advantage Theory, explains that institutional factors are the source of differences between countries that can explain the existence of comparative advantage, even in conditions of uniform tastes and uniformity of technology 
across countries. For example, Ricardo explained that differences in institutional factors can explain differences in the levels of wages of workers and levels of profit between countries that trade. Parrinello (2002) also explains that Ohlin has contributed thoughts regarding institutions. Ohlin (1979) argues that the application of non-factor payments policies, such as taxes and social contributions by producers in a country, is likely to have an impact on the competitiveness of producers in producing goods. In addition, Ohlin provides an overview of the role of risk factors and social institutions in terms of investment, production, trade, contracts, delivery of goods, and so on. At the early development of the Global Value Chain (GVC) around the late 1990 s to early 2000s, institutional factors were not widely discussed. Keane (2017) argues that this is because at that time good institutions were assumed to be attached to trade liberalisation policies. However, over time, there was a need to include aspects of domestic institutions and government support in a comprehensive framework for the development of the global value chain.

Our investigation of empirical studies on institutional factors, as one of the determinants of comparative advantage and foreign trade patterns, shows that this topic began to be widely published in the early 2000 s, along with the availability of data that might more comprehensively describe the quality of a country's institutions. Due to data limitation, early empirical studies on this topic mostly used one indicator as an institutional proxy. For example, Anderson and Marcouiller (2002) utilised the security of exchange variable as a proxy for institutional quality. The data used are the result of a survey by the World Economic Forum in 1997 of company executives in 58 countries. The World Economic Forum found that lower institutional quality had a significant negative effect on trade. Another study that uses one variable as an institutional proxy is that by Levchenko (2007) who employed the Rule of Law Index data that were published by the World Bank Worldwide in their Worldwide Governance Indicators (WGI).

Over time, with the availability of more comprehensive data that measure institutional quality, research on the topic has grown significantly. For example, the aforementioned Worldwide Governance Indicators (WGI) data, that have been published by the World Bank since 1996, can reflect the quality of institutions in political, legal, and economic aspects in 175 countries. The WGI measure institutional governance using 6 dimensions, namely, Voice and Accountability, Political Stability and Absence of Violence / Terrorism, Government Effectiveness, Regulatory Quality, Rule of Law, and Control of Corruption. Studies using these data include Babecká Kucharčuková et al. (2012); Gani and Prasad (2006); Iwanow and Kirkpatrick (2007); Méon and Sekkat (2008); and Soeng and Cuyvers (2018). Empirical studies utilising these data are among the most widely used, although with different variations in the use of the index between studies where some use only a few indexes. Other empirical research on this topic also use institutional quality data published by organisations other than the World Bank. These include Angkinand and Chiu (2011); Berkowitz et al. (2006); Krenz (2016); and Ranjan and Lee (2007), who utilise law, 
bureaucracy, and democratic accountability data published by the Political Risk Services (PRS) Group which provides data for 140 countries. Angkinand and Chiu (2011) also used POLITY IV institutional data published by the Centre for Systemic Peace. Another study using the same data is that of Souva et al. (2008). Meanwhile, other researchers have used the Economic Freedom Index published by the Heritage Foundation (such as Faruq 2011; Ranjan and Lee 2007); as well as Corruption Perception Index data published by Transparency International (e.g., Abidin et al. 2013).

Although the institutional focus varies between empirical studies, where there are those that focus either on exporting or importing countries only and those that focus on both, almost all studies show that institutions quality contributes positively to trade. Only the study by Méon and Sekkat (2008) found that institutions have a negative impact on one commodity, namely non-manufactured exports. However, there are some differences in the magnitude of positive impact of institutions on trade. First, regarding type of commodities. Majority of studies are employing total exports in investigating the role of institutions quality on export performance. However, although still limited in numbers, studies using disaggregated exports found that institutions quality are more important for high value commodities rather than raw materials. Using disaggregated export data, studies by Essaji and Fujiwara (2012); Levchenko (2007); and Méon and Sekkat (2008), found that institutions only have an impact on exports of manufactured products or commodities that are capital intensive. These findings support the Trade Network Theory hypothesis which states that transaction costs are more important for differentiated commodities compared to raw materials (Linders, 2004). Essaji and Fujiwara (2012) also argue that the production of high value-added products requires high-value input, in which good institutions become its supporting capacity (ceteris paribus) due to a high level of contract compliance being required. Second, empirical researches also highlight different role of domestic/exporter vis. a vis foreign/importer institutions on exports. Linders (2004) and Francois and Manchin (2013) conducted research on the effect of the institutional quality of exporters' and importers' on their bilateral trade. The results show that institutional factors have a positive and significant effect on trade, but with a larger coefficient on the exporter side. This shows that the quality of the domestic institutions of the exporting country plays an important role in export performance. The findings of several empirical studies also support the argument for the importance of domestic institutions in providing incentives to high-value commodity producers. These include Essaji and Fujiwara (2012); Francois and Manchin (2013); Levchenko (2007); Méon and Sekkat (2008); and Ranjan and Lee (2007).

The primary objective of this research is to analyse the role of domestic and trading partner institutions on Indonesian export in the era of the global value chain, and will be elaborated in the following way. Firstly, the role of institutions will be considered in exports of four different product categories, namely, raw material, intermediate, capital, and 
consumer goods. As suggested in the literature, the institutional impact on exports may differ between primary products and manufactured products. Therefore, it is important to analyse whether differences in institutional influence exist on each commodity group. Secondly, the study will evaluate whether there are different roles of institutions, domestic and trading partner institutions, on Indonesian export of the four commodities. Thirdly, this study will also evaluate whether the qualities of institutions are more important than tariff reductions, as a proxy for free trade agreements by Indonesia, on export of the group of four commodities.

The novelty and contribution of this paper to the body of economic literature on institutions and trade, resides through its rather disaggregated nature of commodities under consideration. Firstly, given the fact that there is a rather limited number of studies in the literature that analyse the effect of institutions based on different groups of export commodities, this study will shed some light on how institutions might affect export across different commodities. Secondly, given the current microeconomic reform in Indonesia as a developing country, the results of this study might be useful for further policy improvements in Indonesia, as well as developing countries in general in an attempt to be more integrated into the global value chain.

\section{Methodology and data analysis.}

Based on literature studies on this topic, most of the previous studies used the gravity model as a tool for analysis, as does the present research. Notwithstanding, the gravity model has a good ability to explain the determinants of international trade, and this model is also flexible enough to adjust to the characteristics of variables and data. Several independent variables in the research model of Soeng and Cuyvers (2018) and Trung et al. (2018) were selected to be used in the present study, based on two main considerations: (a) adjusting to the research objectives and (b) its relevance to the Indonesian context as a number of studies examining Indonesia's export performance have found that internal conditions are one of the main constraining factors for Indonesian exports. For instance, those two studies did not include the tariff variable in their research. The present study includes bilateral tariffs with consideration to avoid the omitted variable bias problem. Jansen and Nordås (2004) stated that not including the tariff variable in the gravity model to analyse international trade patterns is very largely facing the problem of omitted variable bias. Besides this modelling justification, another supporting argument to include tariff in the equation is also based on the fact that Indonesia has several trade agreements with its trading partner (i.e., tariff reduction). We also include exchange rate as independent variable given the fact that a number of empirical studies revealed that exchange rate plays a vital role in explaining Indonesia's export. Finally, this study also includes trading partners' institutional quality as 
independent variable to examine whether they are having different impacts on exports of the four commodities under consideration. Thus, the model to be estimated is as follow:

$$
\begin{aligned}
& L E X P_{i j, t}=\beta_{0}+\beta_{1} \text { LGDPCap }_{j t}+\beta_{2} \text { LPop }_{j t}+\beta_{3} E R_{t}+\beta_{4} \text { LDist }_{i j}+\beta_{5} \text { Tariff }_{i j, t}+\beta_{6} \text { LTPIns }_{j t}+ \\
& \beta_{7} \text { LIns }_{i t}+e_{i t}
\end{aligned}
$$

where the Dependent variable (LEXP) is Indonesia export value to its trading partner ( $\mathrm{j}$ ) in a group of four commodities (i), i.e., raw material; intermediate goods; capital goods; and consumer goods. The above equation (Eq. 1) suggests that Indonesia exports value is influenced by Indonesia domestic institutions (Ins); exchange rate of Indonesia Rupiah (ER); population of trading partner (Pop); income per capita of trading partner (GDPCap); distance between Indonesia and trading partner (DIST); and import tariff rate imposed by trading partner on four commodities imported from Indonesia (Tariff) and trading partners' institutions quality (TPIns). L denotes values in natural logarithm. Table 3 depicts the definition and data sources of variables.

\begin{tabular}{|c|c|c|}
\hline & Definition & Sources \\
\hline $\begin{array}{l}\text { Dependent Variable } \\
\operatorname{Exp}_{\mathrm{ij}, \mathrm{t}}\end{array}$ & $\begin{array}{l}\text { Indonesia Export of Commodity Group (i) } \\
\text { to trading partner }(\mathrm{j}) \text { at time }(\mathrm{t}) \text {. } \\
\text { Four groups of commodities based on } \\
\text { UNCTAD classification: raw material, } \\
\text { intermediate goods, consumer goods, } \\
\text { capital goods }\end{array}$ & $\begin{array}{l}\text { World Integrated Trade Solution } \\
\text { (WITS) database. }\end{array}$ \\
\hline $\begin{array}{l}\text { Independent Variable } \\
\text { GDPCap }_{j}\end{array}$ & Income per Capita of trading partner & $\begin{array}{l}\text { International Monetary Fund } \\
\text { (IMF) Database }\end{array}$ \\
\hline Pop $_{j}$ & Population of trading partner & $\begin{array}{l}\text { International Monetary Fund } \\
\text { (IMF) Database }\end{array}$ \\
\hline ER & $\begin{array}{l}\text { Real Exchange Rate Index of Rupiah to US } \\
\text { Dollar }(2010=100)\end{array}$ & $\begin{array}{l}\text { Bank of International Settlement } \\
\text { database }\end{array}$ \\
\hline Dist $_{i j}$ & $\begin{array}{l}\text { Bilateral distance between Indonesia and } \\
\text { trading partner }\end{array}$ & CEPII Geodist Database \\
\hline Tariff $_{\mathrm{ij}, \mathrm{t}}$ & $\begin{array}{l}\text { Effective applied tariff of commodity } \\
\text { group (i) imposed by trading partner (j) on } \\
\text { imported goods from Indonesia }\end{array}$ & $\begin{array}{l}\text { World Integrated Trade Solution } \\
\text { (WITS) database }\end{array}$ \\
\hline TPIns $_{\mathrm{j}, \mathrm{t}}$ & $\begin{array}{l}\text { Four dimensions of institutions for } \\
\text { Indonesia Trading Partner }\end{array}$ & $\begin{array}{l}\text { The World Governance Indicators } \\
\text { (WGI) database }\end{array}$ \\
\hline Ins $s_{i, t}$ & $\begin{array}{l}\text { Four dimensions of Indonesia institutions } \\
\text { quality }\end{array}$ & $\begin{array}{l}\text { The World Governance Indicators } \\
\text { (WGI) database }\end{array}$ \\
\hline
\end{tabular}

Table 3 Definition and data sources of variables 
The gravity model above will be estimated using a panel of data on Indonesia's exports to its 18 trading partner countries (countries are listed in Appendix 1). Based on 2018 data, Indonesia has a market share of at least $1 \%$ in these 18 countries, and they represent around $85 \%$ of Indonesia's exports. The main variable to be analysed in this study is the institutional variable. The data for institutional variables that will be used in this study are from The World Governance Indicators (WGI) developed by the World Bank with the consideration that these data are the most widely used in various previous empirical studies. Referring to Kaufmann et al., (2010), there are four dimensions that are directly related to the topic of the present study. The four dimensions are (a) Government Effectiveness and (b) Regulatory Quality, where these two dimensions indicate the government's capacity to formulate and implement good policies; (c) Rule of Law and (d) Control for Corruption which reflect how existing institutions regulate economic and social interactions between communities and their governments. Two dimensions of institutions related to politics, namely Voice and Accountability, Political Stability, and Absence of Violence / Terrorism were not included in this study because previous empirical research argued that although political factors affect trade, they are not as big as those directly related to economic institutions (Ranjan and Lee, 2007; Souva et al., 2008). This database has several advantages over other institutional databases. Firstly, WGI measures institutional quality in a relatively comprehensive manner that is relative to the other database as it is using 6 dimensions, namely Voice and Accountability, Political Stability and Absence of Violence / Terrorism, Government Effectiveness, Regulatory Quality, Rule of Law, and Control of Corruption. Another advantage of this database is that, since it is computed from different data sources, any error or bias in the data computation is likely to be reduced in comparison to other data sources (Borrmann et al., 2006).

The following information describes the estimation strategy of the gravity model above. Firstly, since the four dimensions of World Governance Indicators are highly correlated, putting all the dimensions of institutional quality index in one model would lead to the problem of multicollinearity. To avoid this problem, separate regression models are estimated to assess each of the institutions' dimensions. Hence, there are four regression models for each commodity group as shown in Eqs. (2) to (5) below:

$$
\begin{aligned}
& L E X P_{i j, t}=\beta_{0}+\beta_{1} L_{\text {GDPCap }}+\beta_{2} \text { LPop }_{j t}+\beta_{3} E R_{t}+\beta_{4} L \text { Dist }_{i j}+\beta_{5} \text { Tariff }_{i j, t}+\beta_{6} \text { LTPCC }_{j t}+ \\
& \beta_{7} L C C_{i t}+e_{i t} \\
& L E X P_{i j, t}=\beta_{0}+\beta_{1} L G D P C a p_{j t}+\beta_{2} L P o p_{j t}+\beta_{3} E R_{t}+\beta_{4} L_{D i s t} t_{i j}+\beta_{5} \text { Tariff }_{i j, t}+\beta_{6} L T P G E_{j t}+ \\
& \beta_{7} L G E_{i t}+e_{i t}
\end{aligned}
$$




$$
\begin{aligned}
& L E X P_{i j, t}=\beta_{0}+\beta_{1} L G D P C a p_{j t}+\beta_{2} L_{P o p} j t+\beta_{3} E R_{t}+\beta_{4} L_{\text {Dist }}+\beta_{5} \text { Tariff }_{i j, t}+\beta_{6} L T P R Q_{j t}+ \\
& \beta_{7} L R Q_{i t}+e_{i t} \\
& L E X P_{i j, t}=\beta_{0}+\beta_{1} L G D P C a p_{j t}+\beta_{2} L \text { oop }_{j t}+\beta_{3} E R_{t}+\beta_{4} L \text { Dist }_{i j}+\beta_{5} \text { Tariff }_{i j, t}+\beta_{6} L T P R L_{j t}+ \\
& \beta_{7} L R L_{i t}+e_{i t}
\end{aligned}
$$

where CC and TCC are the index of control of corruption for Indonesia and 18 trading partners, respectively, GE and TGE are the index for government effectiveness for Indonesia and 18 trading partners, respectively; RQ and TRQ are the index of regulatory quality for Indonesia and 18 trading partners, respectively; and lastly RL and TRL are the index of rule of law for Indonesia and 18 trading partners, respectively. Secondly, given the institutional index data are range from -2.5 to 2.5 , we apply a transformation of the data to value between $0-10$ in order to be able to apply log natural to the institutional quality variable.

Lastly, regarding the estimation method, we consider the use of the linear and nonlinear methods as suggested by recent literature on estimation of gravity model in analysing bilateral trade. The literature on gravity estimations suggests that one should consider two main issues in estimating panel data of the gravity model, namely, the presence of nonconstant variance or heteroskedasticity and autocorrelation. If these two exists, an estimation of the Ordinary Least Square (OLS) method on logarithmic models leads to inconsistent estimates (Santos Silva and Tenreyro, 2006). The literature also highlights another important issue, which is the problem of zero trade flow in the export-import data (dependent variable) for gravity estimation, particularly for a high number of samples. There are alternative estimation methods to the gravity model in the presence these problems that have been widely used in the literature, namely, non-linear method, such as Feasible Generalized Least Squares (FGLS), Poisson Pseudo Maximum Likelihood Method (PPML), Gamma Pseudo Maximum Likelihood (GPML), and the Heckman two-step method. Other authors also suggest to consider dataset characteristics when deciding a particular method to be employed.

Table 4 summarises the descriptive statistics of the data. 
Table 4 Descriptive Statistics Source: authors' calculation

\begin{tabular}{lccccc}
\hline Variable & Obs & Mean & Std. Dev. & Min & Max \\
\hline \hline LExp_Raw & 342 & 20,328 & 1,569 & 15,293 & 23,327 \\
LExp_Intermediate & 342 & 20,690 & 0,985 & 18,103 & 23,018 \\
LExp_Consumer & 342 & 20,667 & 1,239 & 17,223 & 23,226 \\
LExp_Capital & 342 & 19,341 & 1,553 & 14,071 & $\mathbf{2 2 , 1 4 2}$ \\
\hline LGDPCap & 342 & 9,158 & 1,615 & 5,966 & 11,129 \\
LPop & 342 & 18,099 & 1,455 & 15,209 & 21,055 \\
LDist & 342 & 8,400 & 0,799 & 6,766 & 9,647 \\
ER & 342 & 87,596 & 8,906 & 65,847 & 100 \\
Tariff_Raw & 342 & 2,67 & 4,61 & 0,00 & 26,30 \\
Tariff_Intermediate & 342 & 5,90 & 13,99 & 0,00 & 78,70 \\
Tariff_Consumer & 342 & 8,38 & 13,48 & 0,00 & 94,86 \\
Tariff_Capital & 342 & 3,87 & 5,81 & 0,00 & 30,84 \\
LTPCC & 342 & 1,743 & 0,393 & 0,697 & 2,267 \\
LTPGE & 342 & 1,851 & 0,300 & 1,156 & 2,290 \\
LTPRQ & 342 & 1,804 & 0,332 & 1,010 & 2,254 \\
LTPRL & 342 & 1,786 & 0,334 & 1,066 & 2,193 \\
LCC & 342 & 1,269 & 0,137 & 0,998 & 1,503 \\
LGE & 342 & 1,506 & 0,074 & 1,395 & 1,679 \\
LRQ & 342 & 1,453 & 0,100 & 1,226 & 1,581 \\
LRL & 342 & 1,323 & 0,097 & 1,154 & 1,475 \\
& & & & &
\end{tabular}

\section{Empirical Results and Discussion}

This section presents an analysis based on the estimation outputs of Eqs. (2) to (5). As previously described, estimation of the logarithm gravity model needs to take into account the problems of heteroscedasticity and zero trade data. Firstly, in an estimation attempt employing OLS method to Eqs. (2) to (5), we found the presence of the heteroscedasticity problem in three commodity groups estimations: raw materials, intermediate, and consumer goods; and also autocorrelation problems for all commodities. In addition, despite the fact of there being no zero trade data in our samples, some tariff data are indeed zero, therefore, in this case the zero data issue might present itself. Taking into consideration the two problems which are present in our study, the use of non-linear estimation is imperative to provide consistent results. Given that each non-linear method has its advantages/disadvantages (Gómez-Herrera, 2013), we decided to use the Feasible Generalized Least Squares (FGLS) method in this study, based on the considerations that (a) it is more suitable for a small sample size (Barton, 2019) and this study might be considered as using a small sample as it uses 18 countries instead of all of the Indonesia trading partners; (b) some studies that compare different methods for gravity models also show that FGLS has more superiority compared to other methods (e.g., Doyle and Martinez-Zarzoso, 2011; Martínez-Zarzoso, 2013; Sy et al., 2020). For comparison and the robustness check, we also provide estimation outputs using the Poisson Pseudo Maximum Likelihood Method (PPML) as suggested by a number of authors (e.g., Álvarez et al., 2018; Francois and Manchin, 2013; Silva and Tenreyro, 2006) to be a consistent and unbiased estimator in the presence of heteroscedasticity and the zero data problem. Tables 5 and 6 present the results estimation outputs from the application of the FGLS and PPML methods. 
Table 5 Estimation outputs of the FGLS method Source: authors' calculation

\begin{tabular}{|c|c|c|c|c|c|c|c|c|c|c|c|c|c|c|c|c|}
\hline & \multicolumn{4}{|c|}{ Export of Raw Material } & \multicolumn{4}{|c|}{ Export of Intermediate Goods } & \multicolumn{4}{|c|}{ Export of Consumer Goods } & \multicolumn{4}{|c|}{ Export of Capital Goods } \\
\hline & (1) & (2) & (3) & (4) & (1) & (2) & (3) & (4) & (1) & (2) & (3) & (4) & (1) & (2) & (3) & (4) \\
\hline LGDPCap & $\begin{array}{l}0.748^{* * *} \\
(0.000)\end{array}$ & $\begin{array}{l}0.701^{* * *} \\
(0.000)\end{array}$ & $\begin{array}{l}0.730^{* * *} \\
(0.000)\end{array}$ & $\begin{array}{l}0.734^{* * *} \\
(0.000)\end{array}$ & $\begin{array}{l}0.103^{* *} \\
(0.023)\end{array}$ & $\begin{array}{l}0.0677 \\
(0.128)\end{array}$ & $\begin{array}{l}0.101^{* *} \\
(0.030)\end{array}$ & $\begin{array}{l}0.0930^{* *} \\
(0.040)\end{array}$ & $\begin{array}{l}0.346^{* * *} \\
(0.000)\end{array}$ & $\begin{array}{l}0.317^{* * *} \\
(0.000)\end{array}$ & $\begin{array}{l}\begin{array}{l}0.351 * * * \\
(0.000)\end{array} \\
\end{array}$ & $\begin{array}{l}0.338^{* * *} \\
(0.000)\end{array}$ & \begin{tabular}{|l}
$0.370^{* * *}$ \\
$(0.000)$
\end{tabular} & $\begin{array}{l}0.281^{* * *} \\
(0.000)\end{array}$ & $\begin{array}{l}0.315^{* * *} \\
(0.000)\end{array}$ & $\begin{array}{l}0.386^{* * *} \\
(0.000)\end{array}$ \\
\hline LPop & $\begin{array}{l}0.504^{* * *} \\
(0.000)\end{array}$ & $\begin{array}{l}0.503^{* * *} \\
(0.000)\end{array}$ & $\begin{array}{l}0.486^{* * *} \\
(0.000)\end{array}$ & $\begin{array}{l}0.512^{* * *} \\
(0.000)\end{array}$ & $\begin{array}{l}0.146 * * * \\
(0.001)\end{array}$ & $\begin{array}{l}0.154^{* * *} \\
(0.000)\end{array}$ & $\begin{array}{l}0.141^{* * *} \\
(0.002)\end{array}$ & $\begin{array}{l}0.148 * * * \\
(0.001)\end{array}$ & $\begin{array}{l}0.310^{* * *} \\
(0.000)\end{array}$ & $\begin{array}{l}0.317^{* * *} \\
(0.000)\end{array}$ & $\begin{array}{l}0.309^{* * *} \\
(0.000)\end{array}$ & $\begin{array}{l}0.311^{* * *} \\
(0.000)\end{array}$ & $\begin{array}{l}0.264 * * * \\
(0.000)\end{array}$ & $\begin{array}{l}0.255^{* * *} \\
(0.000)\end{array}$ & $\begin{array}{l}0.231^{* * *} \\
(0.001)\end{array}$ & $\begin{array}{l}0.288^{* * *} \\
(0.000)\end{array}$ \\
\hline ER & $\begin{array}{l}0.0283^{* * *} \\
(0.001)\end{array}$ & $\begin{array}{l}0.0295^{* * *} \\
(0.000)\end{array}$ & $\begin{array}{l}0.0277^{* * *} \\
(0.000)\end{array}$ & $\begin{array}{l}0.0280^{* * *} \\
(0.000)\end{array}$ & $\begin{array}{l}0.0262^{* * *} \\
(0.000)\end{array}$ & $\begin{array}{l}0.0326 * * * \\
(0.000)\end{array}$ & $\begin{array}{l}0.0327^{* * *} \\
(0.000)\end{array}$ & $\begin{array}{l}0.0282^{* * *} \\
(0.000)\end{array}$ & $\begin{array}{l}0.0148^{* *} \\
(0.027)\end{array}$ & $\begin{array}{l}0.0233^{* * *} \\
(0.000)\end{array}$ & $\begin{array}{l}0.0262^{* * *} \\
(0.000)\end{array}$ & $\begin{array}{l}0.0176^{* * *} \\
(0.005)\end{array}$ & $\begin{array}{l}0.0181^{* *} \\
(0.039)\end{array}$ & $\begin{array}{l}0.0222^{* * *} \\
(0.003)\end{array}$ & $\begin{array}{l}0.0222^{* * *} \\
(0.004)\end{array}$ & $\begin{array}{l}0.0186^{* *} \\
(0.028)\end{array}$ \\
\hline Ldist & $\begin{array}{l}-0.790^{* * *} \\
(0.000)\end{array}$ & $\begin{array}{l}-0.801^{* * *} \\
(0.000)\end{array}$ & $\begin{array}{l}-0.689 * * * \\
(0.000)\end{array}$ & $\begin{array}{l}-0.784^{* * *} \\
(0.000)\end{array}$ & $\begin{array}{l}0.152^{* *} \\
(0.048)\end{array}$ & $\begin{array}{l}0.115 \\
(0.120)\end{array}$ & $\begin{array}{l}0.190^{* *} \\
(0.011)\end{array}$ & $\begin{array}{l}0.152^{* *} \\
(0.046)\end{array}$ & $\begin{array}{l}-0.0790 \\
(0.366)\end{array}$ & $\begin{array}{l}-0.0866 \\
(0.309)\end{array}$ & $\begin{array}{l}-0.0227 \\
(0.793)\end{array}$ & $\begin{array}{l}-0.0713 \\
(0.411)\end{array}$ & $\begin{array}{l}-0.218^{*} \\
(0.062)\end{array}$ & $\begin{array}{l}-0.208^{*} \\
(0.055)\end{array}$ & $\begin{array}{l}-0.0744 \\
(0.521)\end{array}$ & $\begin{array}{l}-0.190 \\
(0.111)\end{array}$ \\
\hline Tariff_Raw & $\begin{array}{l}-0.0227 \\
(0.197)\end{array}$ & $\begin{array}{l}-0.0287^{*} \\
(0.095)\end{array}$ & $\begin{array}{l}-0.0228 \\
(0.203)\end{array}$ & $\begin{array}{l}-0.0250 \\
(0.157)\end{array}$ & & & & & & & & & & & & \\
\hline Tarif_Intermediate & & & & & $\begin{array}{l}-0.0113^{* * *} \\
(0.003)\end{array}$ & $\begin{array}{l}-0.0144^{* * *} \\
(0.000)\end{array}$ & $\begin{array}{l}-0.0109^{* * *} \\
(0.006)\end{array}$ & $\begin{array}{l}-0.0117^{* * *} \\
(0.003)\end{array}$ & & & & & & & & \\
\hline Tariff_Consumer & & & & & & & & & $\begin{array}{l}-0.0103^{* *} \\
(0.029)\end{array}$ & $\begin{array}{l}-0.0127^{* * *} \\
(0.007)\end{array}$ & $\begin{array}{l}-0.00974^{* *} \\
(0.048)\end{array}$ & $\begin{array}{l}-0.00951^{* *} \\
(0.044)\end{array}$ & & & & \\
\hline Tariff_Capital & & & & & & & & & & & & & $\begin{array}{l}0.00767 \\
(0.636)\end{array}$ & $\begin{array}{l}-0.00191 \\
(0.899)\end{array}$ & $\begin{array}{l}0.00629 \\
(0.702)\end{array}$ & $\begin{array}{l}0.0133 \\
(0.423)\end{array}$ \\
\hline LTPCC & $\begin{array}{l}0.986^{* * *} \\
(0.000)\end{array}$ & & & & $\begin{array}{l}0.409 * * * \\
(0.002)\end{array}$ & & & & $\begin{array}{l}0.738^{* * *} \\
(0.000)\end{array}$ & & & & $\begin{array}{l}1.867^{* * *} \\
(0.000)\end{array}$ & & & \\
\hline LCC & \begin{tabular}{|l}
0.274 \\
$(0.611)$
\end{tabular} & & & & $\begin{array}{l}1.403^{* * *} \\
(0.000)\end{array}$ & & & & \begin{tabular}{|l}
$2.169 * * *$ \\
$(0.000)$
\end{tabular} & & & & $\begin{array}{l}0.909 \\
(0.116)\end{array}$ & & & \\
\hline LTPGE & & $\begin{array}{l}1.646 * * * \\
(0.000)\end{array}$ & & & & $\begin{array}{l}0.934 * * * \\
(0.000)\end{array}$ & & & & $\begin{array}{l}1.199 * * * \\
(0.000)\end{array}$ & & & & $\begin{array}{l}2.973^{* * *} \\
(0.000)\end{array}$ & & \\
\hline LGE & & $\begin{array}{l}0.334 \\
(0.696)\end{array}$ & & & & $\begin{array}{l}2.027^{* * *} \\
(0.001)\end{array}$ & & & & $\begin{array}{l}3.284^{* * *} \\
(0.000)\end{array}$ & & & & $\begin{array}{l}1.405 \\
(0.112)\end{array}$ & & \\
\hline LTPRQ & & & $\begin{array}{l}0.916^{* * *} \\
(0.000)\end{array}$ & & & & $\begin{array}{l}0.370^{* *} \\
(0.021)\end{array}$ & & & & $\begin{array}{l}0.682 * * * \\
(0.000)\end{array}$ & & & & $\begin{array}{l}2.119 * * * \\
(0.000)\end{array}$ & \\
\hline LRQ & & & $\begin{array}{l}0.800 \\
(0.209)\end{array}$ & & & & $\begin{array}{l}1.811^{* * *} \\
(0.000)\end{array}$ & & & & $\begin{array}{l}2.288^{* * *} \\
(0.000)\end{array}$ & & & & $\begin{array}{l}1.121^{*} \\
(0.099)\end{array}$ & \\
\hline LTPRL & & & & $\begin{array}{l}1.182^{* * *} \\
(0.000)\end{array}$ & & & & $\begin{array}{l}0.525^{* * *} \\
(0.001)\end{array}$ & & & & $\begin{array}{l}0.876^{* * *} \\
(0.000)\end{array}$ & & & & $\begin{array}{l}1.987^{* * *} \\
(0.000)\end{array}$ \\
\hline LRL & & & & $\begin{array}{l}0.402 \\
(0.576)\end{array}$ & & & & $\begin{array}{l}1.952^{* * *} \\
(0.000)\end{array}$ & & & & $\begin{array}{l}3.100^{* * *} \\
(0.000)\end{array}$ & & & & $\begin{array}{l}1.196 \\
(0.131)\end{array}$ \\
\hline _cons & $\begin{array}{l}6.507^{* * *} \\
(0.000) \\
\end{array}$ & $\begin{array}{l}5.482^{* * *} \\
(0.000) \\
\end{array}$ & $\begin{array}{l}5.452^{* * *} \\
(0.000) \\
\end{array}$ & $\begin{array}{l}5.888^{* * *} \\
(0.000) \\
\end{array}$ & $\begin{array}{l}11.11^{* * *} \\
(0.000) \\
\end{array}$ & $\begin{array}{l}8.760^{* * *} \\
(0.000) \\
\end{array}$ & $\begin{array}{l}9.528^{* * *} \\
(0.000) \\
\end{array}$ & $\begin{array}{l}9.963^{* * *} \\
(0.000) \\
\end{array}$ & $\begin{array}{l}7.305^{* * *} \\
(0.000) \\
\end{array}$ & $\begin{array}{l}3.659 * * * \\
(0.003) \\
\end{array}$ & $\begin{array}{l}5.297 * * * \\
(0.000) \\
\end{array}$ & $\begin{array}{l}5.423^{* * *} \\
(0.000) \\
\end{array}$ & \begin{tabular}{|l}
$6.976 * * *$ \\
$(0.000)$ \\
\end{tabular} & $\begin{array}{l}4.342^{* * *} \\
(0.006) \\
\end{array}$ & $\begin{array}{l}5.478^{* * *} \\
(0.000) \\
\end{array}$ & $\begin{array}{l}5.385^{* * *} \\
(0.000) \\
\end{array}$ \\
\hline $\mathrm{N}$ & 342 & 342 & 342 & 342 & 342 & 342 & 342 & 342 & 342 & 342 & 342 & 342 & 342 & 342 & 342 & 342 \\
\hline
\end{tabular}


Table 6 Estimation outputs of PPML method Source: authors' calculation

\begin{tabular}{|c|c|c|c|c|c|c|c|c|c|c|c|c|c|c|c|c|}
\hline & \multicolumn{4}{|c|}{ Export of Raw Material } & \multicolumn{4}{|c|}{ Export of Intermediate Goods } & \multicolumn{4}{|c|}{ Export of Consumer Goods } & \multicolumn{4}{|c|}{ Export of Capital Goods } \\
\hline & (1) & (2) & (3) & (4) & (1) & (2) & (3) & (4) & (1) & (2) & (3) & (4) & (1) & (2) & (3) & (4) \\
\hline$\overline{~ L G D P C a p}$ & $\begin{array}{l}0.0371^{* * *} \\
(0.000)\end{array}$ & $\begin{array}{l}0.0348^{* * *} \\
(0.000)\end{array}$ & $\begin{array}{l}0.0361^{* * *} \\
(0.000)\end{array}$ & $\begin{array}{l}0.0364 * * * \\
(0.000)\end{array}$ & $\begin{array}{l}0.00496^{* * *} \\
(0.005)\end{array}$ & $\begin{array}{l}0.00330^{* *} \\
(0.049)\end{array}$ & $\begin{array}{l}0.00488^{* *} \\
(0.010)\end{array}$ & $\begin{array}{l}0.00450^{* *} \\
(0.012)\end{array}$ & $\begin{array}{l}0.0169^{* * *} \\
(0.000)\end{array}$ & $\begin{array}{l}0.0155^{* * *} \\
(0.000)\end{array}$ & $\begin{array}{l}0.0170^{* * *} \\
(0.000)\end{array}$ & $\begin{array}{l}0.0165^{* * *} \\
(0.000)\end{array}$ & $\begin{array}{l}0.0198^{* * *} \\
(0.000)\end{array}$ & $\begin{array}{l}0.0154^{* * *} \\
(0.000)\end{array}$ & $\begin{array}{l}0.0170^{* * *} \\
(0.000)\end{array}$ & $\begin{array}{l}0.0206^{* * *} \\
(0.000)\end{array}$ \\
\hline LPop & $\begin{array}{l}0.0250^{* * *} \\
(0.000)\end{array}$ & $\begin{array}{l}0.0249 * * * \\
(0.000)\end{array}$ & $\begin{array}{l}0.0240^{* * *} \\
(0.000)\end{array}$ & $\begin{array}{l}0.0254 * * * \\
(0.000)\end{array}$ & $\begin{array}{l}0.00705^{* * *} \\
(0.005)\end{array}$ & $\begin{array}{l}0.00748^{* * *} \\
(0.003)\end{array}$ & $\begin{array}{l}0.00679 * * * \\
(0.006)\end{array}$ & $\begin{array}{l}0.00715 * * * \\
(0.005)\end{array}$ & $\begin{array}{l}0.0150^{* * *} \\
(0.000)\end{array}$ & $\begin{array}{l}0.0153^{* * *} \\
(0.000)\end{array}$ & $\begin{array}{l}0.0149 * * * \\
(0.000)\end{array}$ & $\begin{array}{l}0.0150^{* * *} \\
(0.000)\end{array}$ & $\begin{array}{l}0.0140 * * * \\
(0.000)\end{array}$ & $\begin{array}{l}0.0136^{* * *} \\
(0.000)\end{array}$ & $\begin{array}{l}0.0122^{* * *} \\
(0.001)\end{array}$ & $\begin{array}{l}0.0151^{* * *} \\
(0.000)\end{array}$ \\
\hline ER & $\begin{array}{l}0.00142^{* * *} \\
(0.001)\end{array}$ & $\begin{array}{l}0.00148^{* * *} \\
(0.000)\end{array}$ & $\begin{array}{l}0.00139 * * * \\
(0.001)\end{array}$ & $\begin{array}{l}0.00141^{* * *} \\
(0.001)\end{array}$ & $\begin{array}{l}0.00129^{* * *} \\
(0.000)\end{array}$ & $\begin{array}{l}0.00160^{* * *} \\
(0.000)\end{array}$ & $\begin{array}{l}0.00159^{* * *} \\
(0.000)\end{array}$ & $\begin{array}{l}0.00139^{* * *} \\
(0.000)\end{array}$ & $\begin{array}{l}0.000749 * * \\
(0.038)\end{array}$ & $\begin{array}{l}0.00115^{* * *} \\
(0.000)\end{array}$ & $\begin{array}{l}0.00128^{* * *} \\
(0.000)\end{array}$ & $\begin{array}{l}0.000880^{* * *} \\
(0.010)\end{array}$ & $\begin{array}{l}0.000943^{* *} \\
(0.039)\end{array}$ & $\begin{array}{l}0.00115^{* * *} \\
(0.003)\end{array}$ & $\begin{array}{l}0.00115^{* * *} \\
(0.004)\end{array}$ & $\begin{array}{l}0.000969 * * \\
(0.030)\end{array}$ \\
\hline Ldist & $\begin{array}{l}-0.0396^{* * *} \\
(0.000)\end{array}$ & $\begin{array}{l}-0.0401^{* * *} \\
(0.000)\end{array}$ & $\begin{array}{l}-0.0343^{* * *} \\
(0.000)\end{array}$ & $\begin{array}{l}-0.0392^{* * *} \\
(0.000)\end{array}$ & $\begin{array}{l}0.00730 * * \\
(0.036)\end{array}$ & $\begin{array}{l}0.00547^{*} \\
(0.100)\end{array}$ & $\begin{array}{l}0.00917^{* * *} \\
(0.005)\end{array}$ & $\begin{array}{l}0.00731^{* *} \\
(0.034)\end{array}$ & $\begin{array}{l}-0.00408 \\
(0.313)\end{array}$ & $\begin{array}{l}-0.00443 \\
(0.246)\end{array}$ & $\begin{array}{l}-0.00124 \\
(0.752)\end{array}$ & $\begin{array}{l}-0.00367 \\
(0.360)\end{array}$ & $\begin{array}{l}-0.0123^{* *} \\
(0.027)\end{array}$ & $\begin{array}{l}-0.0120^{* *} \\
(0.019)\end{array}$ & $\begin{array}{l}-0.00468 \\
(0.393)\end{array}$ & $\begin{array}{l}-0.0106 * \\
(0.075)\end{array}$ \\
\hline Tariff_Raw & \begin{tabular}{|l}
-0.00129 \\
$(0.109)$
\end{tabular} & $\begin{array}{l}-0.00160 * \\
(0.051)\end{array}$ & $\begin{array}{l}-0.00129 \\
(0.121)\end{array}$ & $\begin{array}{l}-0.00140 * \\
(0.091)\end{array}$ & & & & & & & & & & & & \\
\hline Tarif_Intermediate & & & & & $\begin{array}{l}-0.000554^{* * *} \\
(0.000)\end{array}$ & $\begin{array}{l}-0.000706^{* * *} \\
(0.000)\end{array}$ & $\begin{array}{l}-0.000531^{* * *} \\
(0.000)\end{array}$ & $\begin{array}{l}-0.000570^{* * *} \\
(0.000)\end{array}$ & & & & & & & & \\
\hline Tariff_Consumer & & & & & & & & & $\begin{array}{l}-0.000518^{* *} \\
(0.016)\end{array}$ & $\begin{array}{l}-0.000635^{* * *} \\
(0.002)\end{array}$ & $\begin{array}{l}-0.000489 * * \\
(0.019)\end{array}$ & $\begin{array}{l}-0.000477^{* *} \\
(0.024)\end{array}$ & & & & \\
\hline Tariff_Capital & & & & & & & & & & & & & $\begin{array}{l}0.000434 \\
(0.542)\end{array}$ & $\begin{array}{l}-0.0000549 \\
(0.936)\end{array}$ & $\begin{array}{l}0.000371 \\
(0.591)\end{array}$ & $\begin{array}{l}0.000727 \\
(0.305)\end{array}$ \\
\hline LTPCC & $\begin{array}{l}0.0507^{* * *} \\
(0.000)\end{array}$ & & & & $\begin{array}{l}0.0200 * * * \\
(0.002)\end{array}$ & & & & $\begin{array}{l}0.0366 * * * \\
(0.000)\end{array}$ & & & & $\begin{array}{l}0.0984 * * * \\
(0.000)\end{array}$ & & & \\
\hline LCC & $\begin{array}{l}0.0135 \\
(0.630)\end{array}$ & & & & $\begin{array}{l}0.0678^{* * *} \\
(0.001)\end{array}$ & & & & $\begin{array}{l}0.105^{* * *} \\
(0.000)\end{array}$ & & & & $\begin{array}{l}0.0473 \\
(0.114)\end{array}$ & & & \\
\hline LTPGE & & $\begin{array}{l}0.0844^{* * *} \\
(0.000)\end{array}$ & & & & $\begin{array}{l}0.0456^{* * *} \\
(0.000)\end{array}$ & & & & $\begin{array}{l}0.0592^{* * *} \\
(0.000)\end{array}$ & & & & $\begin{array}{l}0.157^{* * *} \\
(0.000)\end{array}$ & & \\
\hline LGE & & $\begin{array}{l}0.0145 \\
(0.743)\end{array}$ & & & & $\begin{array}{l}0.0971^{* * *} \\
(0.002)\end{array}$ & & & & $\begin{array}{l}0.157^{* * *} \\
(0.000)\end{array}$ & & & & $\begin{array}{l}0.0707 \\
(0.131)\end{array}$ & & \\
\hline LTPRQ & & & $\begin{array}{l}0.0471^{* * *} \\
(0.000)\end{array}$ & & & & $\begin{array}{l}0.0181^{* *} \\
(0.019)\end{array}$ & & & & $\begin{array}{l}0.0338^{* * *} \\
(0.000)\end{array}$ & & & & $\begin{array}{l}0.112^{* * *} \\
(0.000)\end{array}$ & \\
\hline LRQ & & & $\begin{array}{l}0.0389 \\
(0.236)\end{array}$ & & & & $\begin{array}{l}0.0880^{* * *} \\
(0.000)\end{array}$ & & & & $\begin{array}{l}0.112^{* * *} \\
(0.000)\end{array}$ & & & & $\begin{array}{l}0.0577 \\
(0.104)\end{array}$ & \\
\hline LTPRL & & & & $\begin{array}{l}0.0604^{* * *} \\
(0.000)\end{array}$ & & & & $\begin{array}{l}0.0256^{* * *} \\
(0.001)\end{array}$ & & & & $\begin{array}{l}0.0432^{* * *} \\
(0.000)\end{array}$ & & & & $\begin{array}{l}0.105 * * * \\
(0.000)\end{array}$ \\
\hline LRL & & & & $\begin{array}{l}0.0191 \\
(0.604)\end{array}$ & & & & $\begin{array}{l}0.0942^{* * *} \\
(0.000)\end{array}$ & & & & $\begin{array}{l}0.149 * * * \\
(0.000)\end{array}$ & & & & $\begin{array}{l}0.0616 \\
(0.129)\end{array}$ \\
\hline _cons & $\begin{array}{l}2.325^{* * *} \\
(0.000) \\
\end{array}$ & $\begin{array}{l}2.274 * * * \\
(0.000) \\
\end{array}$ & $\begin{array}{l}2.274 * * * \\
(0.000) \\
\end{array}$ & $\begin{array}{l}2.294^{* * *} \\
(0.000) \\
\end{array}$ & \begin{tabular}{|l}
$2.564^{* * *}$ \\
$(0.000)$ \\
\end{tabular} & $\begin{array}{l}2.451^{* * *} \\
(0.000) \\
\end{array}$ & $\begin{array}{l}2.488^{* * *} \\
(0.000) \\
\end{array}$ & $\begin{array}{l}2.509 * * * \\
(0.000) \\
\end{array}$ & \begin{tabular}{|l}
$2.378^{* * *}$ \\
$(0.000)$ \\
\end{tabular} & $\begin{array}{l}2.204^{* * *} \\
(0.000) \\
\end{array}$ & $\begin{array}{l}2.281^{* * *} \\
(0.000) \\
\end{array}$ & $\begin{array}{l}2.288^{* * *} \\
(0.000) \\
\end{array}$ & \begin{tabular}{|l}
$2.313^{* * *}$ \\
$(0.000)$
\end{tabular} & $\begin{array}{l}2.176^{* * *} \\
(0.000)\end{array}$ & $\begin{array}{l}2.237^{* * *} \\
(0.000)\end{array}$ & $\begin{array}{l}2.232 * * * \\
(0.000)\end{array}$ \\
\hline $\mathbf{N}$ & 342 & 342 & 342 & 342 & 342 & 342 & 342 & 342 & 342 & 342 & 342 & 342 & 342 & 342 & 342 & 342 \\
\hline
\end{tabular}


Comparing the two estimation output tables above, in general, the estimation methods seem to affect the magnitude and significances in several parameters, but not the sign of the parameters for independent variables. In other words, one would safely argue that PPML method produces smaller coefficients in all independent variables. Despite this, however, slight differences of the significant variable are present in the estimation results. For example, on the estimation of raw material, the tariff of raw material is significantly affecting export value only in Eq. (2) of FGLS strategy, while for PPML are in Eqs. (2) and (4). Another example is on the distance variable of intermediate goods, where PPML estimation results in all distance variable significantly affecting export of raw material, but the FGLS method produces one insignificant parameter (i.e., in Eq. (2)).

As expected, GDP per capita, population, and exchange rate significantly increase export value in all commodity groups. These all are consistent in the two estimation strategies, although the magnitudes are somewhat different. One important note on the exchange rate variable, given the highly significant effect on export performance and the fact that Indonesia Rupiah has been very volatile against major trading currencies, it is imperative for Indonesia policy makers to maintain the Rupiah exchange rate at its competitive level. Regarding the distance variable, we found that distance reduces export on raw material, consumer goods, and capital goods, but not on intermediate goods. To get the expected sign of distance on intermediate goods estimation, we follow the work of Greaney and Kiyota (2020) to consider resampling the estimation using samples of Factory Asia countries, which make up the concentrated manufacturing and supply chain hub in the Asia Pacific region (Japan, China, Malaysia, the Philippines, South Korea, Taiwan, and Thailand) only for the intermediate goods equation. The result, however, is still producing a positive distance coefficient on intermediate goods.

Focusing now on our variables of interest on institutional indicators, we find that both domestic and trading partners' institutions quality display the expected sign in the four commodities group, regardless of the estimation method. That is, all aspects of institutions contribute to the increase of Indonesia exports in the four commodities. Furthermore, institutions' quality variables seem to affect more on Indonesia exports relative to the other variables under consideration, given the fact that coefficients representing institutions are relatively higher than the other variables. The following two tables reproduce estimation outputs only on two variables, namely, institutions' quality and tariffs. 
Table 7 Estimation output for Tariff and Institutional Quality on Raw Material and Capital Goods Export Source: authors' calculation

\begin{tabular}{|c|c|c|c|c|c|c|c|c|c|c|c|c|c|c|c|c|}
\hline \multirow[b]{3}{*}{ Tariff_Raw } & \multicolumn{8}{|c|}{ Export of Raw Material } & \multicolumn{8}{|c|}{ Export of Capital Goods } \\
\hline & \multicolumn{4}{|c|}{ FGLS } & \multicolumn{4}{|c|}{$\begin{array}{l}\text { PPML } \\
\end{array}$} & \multicolumn{4}{|c|}{ FGLS } & \multicolumn{4}{|c|}{$\begin{array}{l}\text { PPML } \\
\end{array}$} \\
\hline & -0.0227 & $-0.0287^{*}$ & -0.0228 & -0.0250 & -0.00129 & $-0.00160^{*}$ & -0.00129 & $-0.00140^{*}$ & & & & & & & & \\
\hline Tariff_Capital & ) & & & & & & & & \begin{tabular}{|c|}
0.00767 \\
$(0.636)$
\end{tabular} & $\begin{array}{r}-0.00191 \\
(0.899)\end{array}$ & $\begin{array}{l}0.00629 \\
(0.702)\end{array}$ & $\begin{array}{l}0.0133 \\
(0.423)\end{array}$ & $\begin{array}{c}0.000434 \\
(0.542)\end{array}$ & $\begin{array}{c}-0.00005499 \\
(0.936)\end{array}$ & $\begin{array}{c}0.000371 \\
(0.591)\end{array}$ & $\begin{array}{c}0.000727 \\
(0.305)\end{array}$ \\
\hline LTPCC & $\begin{array}{c}0.986^{* * *} \\
(0.000)\end{array}$ & & & & $\begin{array}{c}0.0507^{* * *} \\
(0.000)\end{array}$ & & & & $\begin{array}{c}1.867^{* * *} \\
(0.000)\end{array}$ & & & & $\begin{array}{c}0.0984^{* * *} \\
(0.000)\end{array}$ & & & \\
\hline LCC & $\begin{array}{c}0.274 \\
(0.611)\end{array}$ & & & & $\begin{array}{l}0.0135 \\
(0.630)\end{array}$ & & & & $\begin{array}{c}0.909 \\
(0.116)\end{array}$ & & & & $\begin{array}{l}0.0473 \\
(0.114)\end{array}$ & & & \\
\hline LTPGE & & $\begin{array}{c}1.646^{* * * *} \\
(0.000)\end{array}$ & & & & $\begin{array}{c}0.0844^{* * *} \\
(0.000)\end{array}$ & & & & $\begin{array}{r}2.973^{* * *} \\
(0.000)\end{array}$ & & & & $\begin{array}{c}0.157^{* * *} \\
(0.000)\end{array}$ & & \\
\hline LGE & & $\begin{array}{c}0.334 \\
(0.696)\end{array}$ & & & & $\begin{array}{l}0.0145 \\
(0.743)\end{array}$ & & & & $\begin{array}{c}1.405 \\
(0.112)\end{array}$ & & & & $\begin{array}{l}0.0707 \\
(0.131)\end{array}$ & & \\
\hline LTPRQ & & & $\begin{array}{c}0.916^{* * *} \\
(0.000)\end{array}$ & & & & $\begin{array}{c}0.0471^{* * *} \\
(0.000)\end{array}$ & & & & $\begin{array}{c}2.119^{* * *} \\
(0.000)\end{array}$ & & & & $\begin{array}{c}0.112^{* * *} \\
(0.000)\end{array}$ & \\
\hline LRQ & & & $\begin{array}{c}0.800 \\
(0.209)\end{array}$ & & & & $\begin{array}{l}0.0389 \\
(0.236)\end{array}$ & & & & $\begin{array}{l}1.121^{*} \\
(0.099)\end{array}$ & & & & $\begin{array}{l}0.0577 \\
(0.104)\end{array}$ & \\
\hline LTPRL & & & & $\begin{array}{c}1.182^{* * *} \\
(0.000)\end{array}$ & & & & $\begin{array}{c}0.0604^{* * *} \\
(0.000)\end{array}$ & & & & $\begin{array}{c}1.987^{* * *} \\
(0.000)\end{array}$ & & & & $\begin{array}{c}0.105^{* * *} \\
(0.000)\end{array}$ \\
\hline LRL & & & & $\begin{array}{c}0.402 \\
(0.576)\end{array}$ & & & & $\begin{array}{l}0.0191 \\
(0.604)\end{array}$ & & & & $\begin{array}{c}1.196 \\
(0.131)\end{array}$ & & & & $\begin{array}{l}0.0616 \\
(0.129)\end{array}$ \\
\hline _cons & $\begin{array}{c}6.507^{* * *} \\
(0.000)\end{array}$ & $\begin{array}{c}5.482^{* * * *} \\
(0.000)\end{array}$ & $\begin{array}{c}5.452^{* * *} \\
(0.000)\end{array}$ & $\begin{array}{c}5.888^{* * *} \\
(0.000)\end{array}$ & $\begin{array}{c}2.325^{* * *} \\
(0.000)\end{array}$ & $\begin{array}{c}2.274^{* * *} \\
(0.000)\end{array}$ & $\begin{array}{c}2.274^{* * *} \\
(0.000)\end{array}$ & $\begin{array}{c}2.294^{* * *} \\
(0.000)\end{array}$ & \begin{tabular}{|c}
$6.976^{* * *}$ \\
$(0.000)$
\end{tabular} & $\begin{array}{c}4.342^{* * *} \\
(0.006)\end{array}$ & $\begin{array}{c}5.478^{* * *} \\
(0.000)\end{array}$ & $\begin{array}{c}5.385^{* * *} \\
(0.000)\end{array}$ & $\begin{array}{c}2.313^{* * *} \\
(0.000)\end{array}$ & $\begin{array}{c}2.176^{* * *} \\
(0.000)\end{array}$ & $\begin{array}{c}2.237^{* * *} \\
(0.000)\end{array}$ & $\begin{array}{c}2.232^{* * * *} \\
(0.000)\end{array}$ \\
\hline $\mathrm{N}$ & 342 & 342 & 342 & 342 & 342 & 342 & 342 & 342 & 342 & 342 & 342 & 342 & 342 & 342 & 342 & 342 \\
\hline
\end{tabular}

Table 8 Estimation output for Tariff and Institutional Quality on Intermediate and Consumer Goods Export Source: authors' calculation

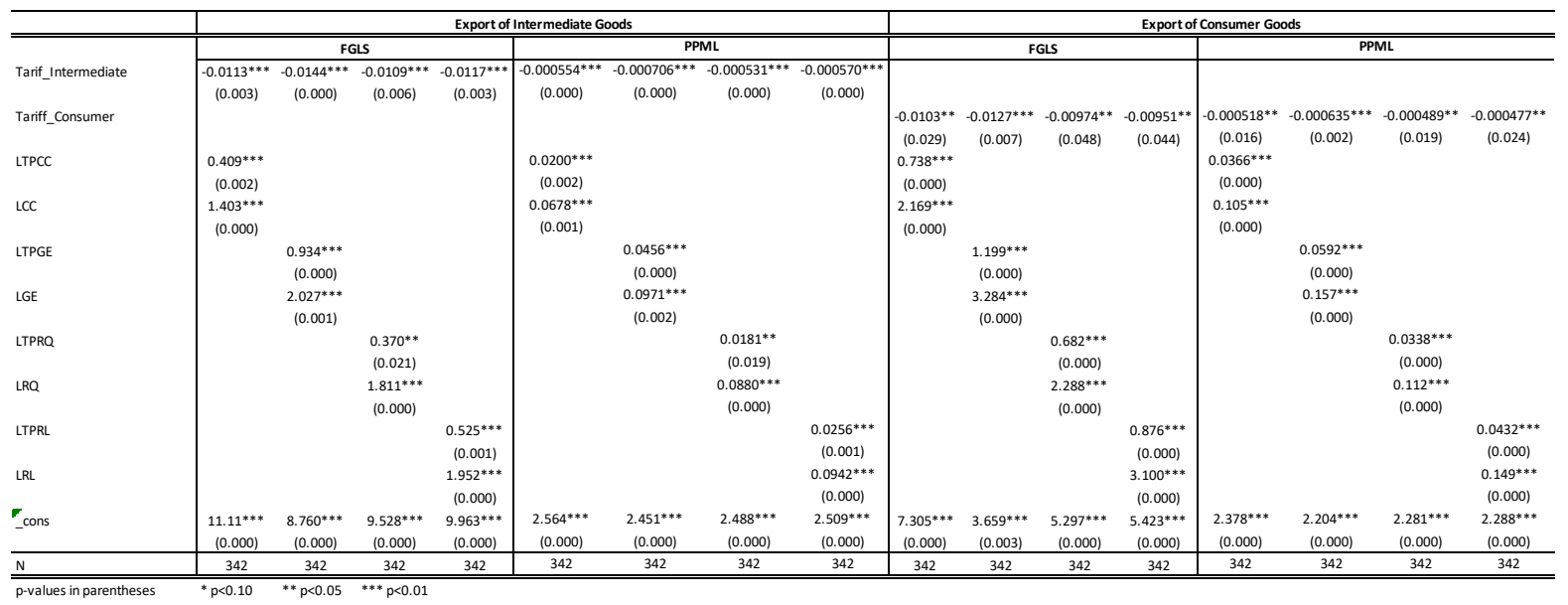

Despite the fact of the four institutions dimension increasing Indonesian exports, we have some interesting findings that might be considered as novel factors of this study. Firstly, on the different role of domestic and the quality of trading partners' institutions among commodity groups. On raw material, both methods suggest trading partners' institutions significantly increases Indonesian export of raw material, while the domestic institutions are insignificant. On capital goods, the two methods produce similar results as the raw material, with one exception on the FGLS method which suggests Indonesia Regulatory Quality contributes significantly to the increase in the Indonesian export of capital goods. On the other hand, on two commodities that are potentials to Indonesia involvement in the global value chain (i.e., intermediate and consumer goods), both domestic and trading partners' institutions quality affect positively and significantly on Indonesian exports of the two commodities. Furthermore, although both domestic and trading partners' institutions increase exports of intermediate and consumer goods, the domestic institutions affect more 
than trading partners, as indicated by the higher coefficients on domestic institutions. These higher magnitudes of domestic institutions are consistently present in four institutional indicators, regardless of the estimation methods. These findings are in line with Essaji and Fujiwara (2012); Levchenko (2007); as well as Méon and Sekkat (2008) who argue that domestic institutions matter more on higher value added products than raw materials. Hence, the results above imply that Indonesia needs to improve its domestic institution quality to be able to increase its involvement in global value chain and shifting from reliance on raw material export to intermediate or consumer goods export.

Secondly, examining individual institution dimensions on commodities' potential for Indonesian involvement in the global value chain (i.e., intermediate and consumer goods), the two estimation results suggest that Indonesia Government Effectiveness and Rule of Law are the two highest institution factors which contribute to Indonesian export commodities on both goods. Government Effectiveness is viewed as a proxy for the ability of a government to deliver efficient and effective policies. This includes the quality of public services, bureaucracy, infrastructure, and public policies that directly and indirectly support the business environment for business transactions and exchanges in exports. An example of government support for export transactions might include trade facilitation. The following table depicts trade facilitation indicators for Indonesia and other exporting countries.

Table 9 Trade facilitation in Time to Export Source: Doing Business Database, The World Bank

\begin{tabular}{c|ccc|ccc}
\hline \multirow{2}{*}{ Countries } & \multicolumn{3}{|c|}{$\begin{array}{c}\text { Time to export, documentary } \\
\text { compliance (hours) }\end{array}$} & \multicolumn{3}{c}{ Time to export, border compliance } \\
& $\mathbf{2 0 1 7}$ & $\mathbf{2 0 1 8}$ & $\mathbf{2 0 1 6}$ & $\mathbf{2 0 1 7}$ & $\mathbf{2 0 1 8}$ \\
\cline { 2 - 7 } & $\mathbf{2 0 1 6}$ & $\mathbf{2 0 1 7}$ & 8.6 & 25.9 & 25.9 & 25.9 \\
China & 21.2 & 21.2 & 14.5 & 106.1 & 106.1 & 66.2 \\
India & 38.4 & 38.4 & 61.3 & 53.3 & 53.3 & 53.3 \\
Indonesia & 62.6 & 61.3 & 10 & 48 & 45 & 28 \\
Malaysia & 10 & 10 & 11 & 51 & 51 & 44 \\
Thailand & 11 & 11 & 50 & 58 & 55 & 55 \\
Vietnam & 50 & 50 & \multicolumn{3}{c}{}
\end{tabular}

Table 9 shows that Indonesia's export facilitation is still poor, which is represented by indicators of document processing time and export processing time at ports. For example, in the indicator of time required in processing export documents, Indonesia has always been in the position over the longest period and there has been no improvement over the past three years. Meanwhile, in terms of port administration, Indonesia's position is only superior to India and Vietnam. However, during this period India has shown significant improvement, Vietnam has improved slightly, while Indonesia has not improved at all. With the lengthy process of managing document and port administration for the implementation of exports, it has an impact that generates higher costs, further reducing the competitiveness of Indonesia's export commodities. 
Furthermore, the second institutional aspect that mostly affects Indonesian export in intermediate and consumer goods is the Rule of Law. The Rule of Law represents confidence in the quality of economic agents, in terms of the legal system in a country which includes a judicial system, contract enforcement, property rights, and law enforcement. Essaji and Fujiwara (2012) argue that a poor contracting environment is hindering product quality improvements by producers. This is based on the consideration that the production of betterquality products, which in the present study might refer to intermediate or consumer goods as opposed to raw materials, requires intense collaboration between suppliers of input and producers of the two products. The production of higher value and better products must be facilitated by the so-called relationship-specific investment between suppliers and producers. In the absence of a decent contract environment, there are increases in business uncertainty and the relationship-specific investment would arguably be difficult to occur. Table 10 illustrates Indonesia's disadvantages in terms of starting a business and contract enforcement in comparison to other exporting countries.

Table 10 Data for Starting a Business and Contract Enforcement in Selected East Asia Major Exporting Countries Source: Doing Business Database, The World Bank

\begin{tabular}{c|cccc|ccc}
\hline \multirow{2}{*}{ Countries } & \multicolumn{3}{|c|}{ Starting a Business (Score) } & \multicolumn{3}{c}{ Enforcing Contract (Score) } \\
\cline { 2 - 8 } & $\mathbf{2 0 0 4}$ & $\mathbf{2 0 1 6}$ & $\mathbf{2 0 1 7}$ & $\mathbf{2 0 1 8}$ & $\mathbf{2 0 1 6}$ & $\mathbf{2 0 1 7}$ & $\mathbf{2 0 1 8}$ \\
\hline China & N/A & 80.7 & 84.3 & 85.3 & 78.1 & 78.9 & 78.9 \\
India & N/A & 71.7 & 72.1 & 73.9 & 36.5 & 39.3 & 41.1 \\
Indonesia & N/A & 65.6 & 74.5 & 76.08 & 42.6 & 45.3 & 47.2 \\
Malaysia & 72.5 & 89.3 & 80 & 80 & 68.2 & 68.2 & 68.2 \\
Thailand & 75.4 & 82.6 & 84.6 & 91.6 & 65.5 & 65.5 & 67.9 \\
Vietnam & 66.1 & 82.7 & 81.7 & 82 & 82.7 & 81.7 & 82.02 \\
\hline \hline
\end{tabular}

Note: Score range $0-100 ; 0=$ the worst and $100=$ the best

In the case of Indonesia, the issue of producers' informal status also gives rise to problems in intermediate goods export. One might argue that the two indicators in Table 10 are correlated. That is, the non-conducive regulation to establish formal/legal businesses requiring high registration costs and extensive time to process, resulting in a large number of informal companies in Indonesia. Their informal status, in turn, makes them impossible to have legal and binding contracts with domestic producers/exporters. At the practical level of export transaction in Indonesia (e.g., agriculture-based processed commodities and low technology manufacturing), one might describe using Figure 1 on how the lack of contracts between domestic suppliers and domestic producers provide another challenge in the export of intermediate goods. Most suppliers of agricultural products are small farmers with no business entities, which are almost impossible to have a legal binding contract with them. In the absence of any formal contract between Indonesian exporters with domestic input suppliers, the exporters face a number of uncertainties in their relationship with the suppliers. These uncertainties include quantity and quality supplied, prices, as well as time of delivery. Thus, in the absence of any formal contract between domestic input suppliers and domestic exporters, not only do the domestic exporters face uncertainty in their production from raw material supply, but also they are more likely to incur higher costs in compliance of the 
agreement with its importer, thereby making them less competitive. Furthermore, another possible drawback from this uncertain business environment, is that it gives disincentive to establishment of new export companies (i.e., new investment) producing intermediate goods for export markets.

\section{Figure 1 Domestic Supplier-Exporter-Importer Relationship Source: authors' observation}

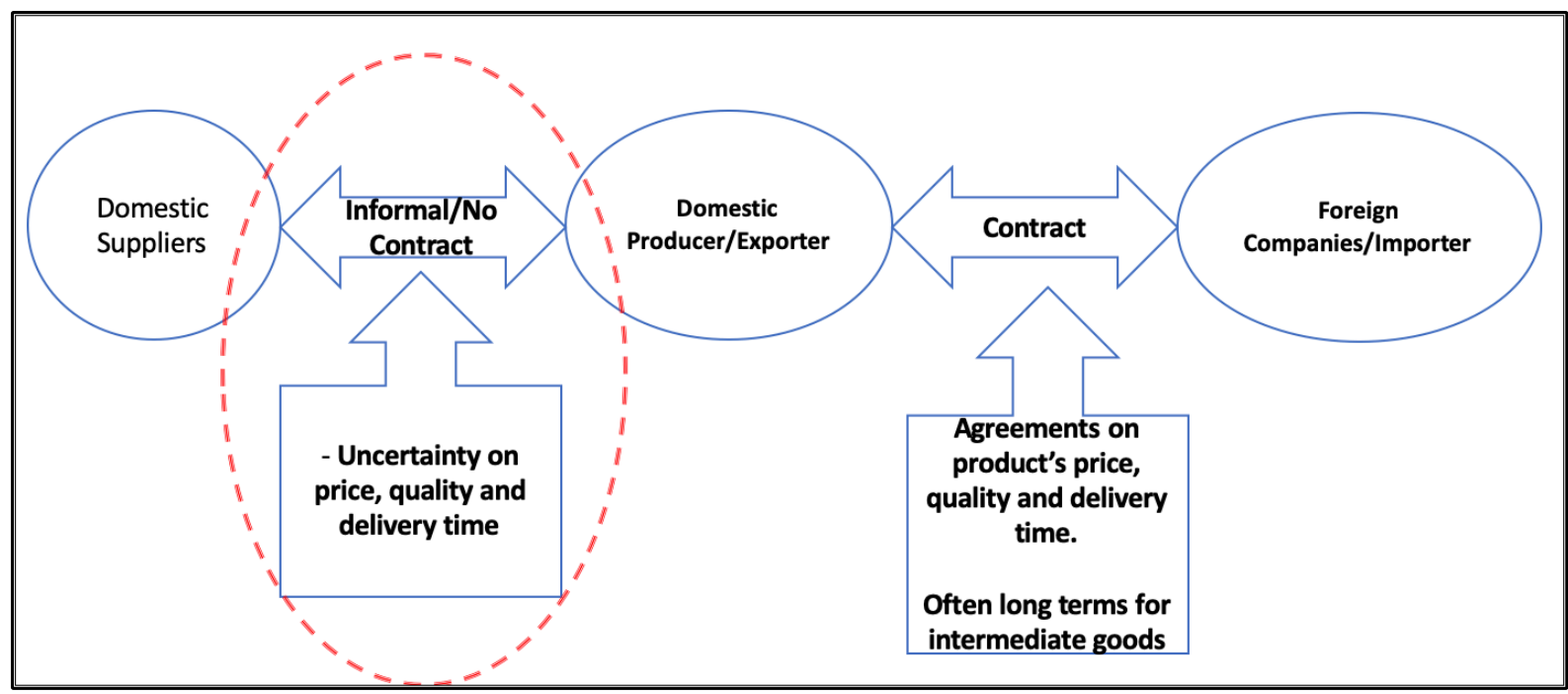

Lastly, on the tariff variable, the estimation of raw material and capital goods equations seems to suggest that tariff reduction is less significant with respect to its export performance. On the other hand, the estimation results show that import tariff reductions by trading partners significantly increase Indonesia export on intermediate and consumer goods. Despite its significances, however, their magnitudes are somewhat much lower than institutional quality parameters. These results, again, suggest that institutional qualities are important; and support the arguments of Dollar and Kraay (2003), Méon and Sekkat (2008), and Jansen and Nordås (2004) that improving the quality of institutions is imperative to compliment tariff reductions through trade liberalisation or free trade agreements. Therefore, it seems safe to argue that Indonesian efforts in increasing export performance through various trade agreements is on the right track, and this must be accompanied with better institutions.

\section{Conclusion}

In the last two decades, East Asia countries have been emerging as the world's main exporters for global value chain activities. This, however, is less likely for Indonesia, despite its endowment resources and export potential. Indonesia has not been able to move its export from raw material dominance to intermediate or consumer goods, hence, this country is less integrated into the global value chain. Recent studies in international trade and institution highlight the importance of the domestic institution in supporting export performance of higher value commodities that are relevant to the global value chain. 
The focus of this paper is to evaluate whether institutions, domestic partners, and trading partners, as well as import tariff by trading partners explain Indonesian export performance on four groups of commodities (raw material, intermediate, capital, and consumer goods) in the global value chain era. Different estimation methods for the gravity model were used to analyse the Indonesian bilateral trade with 19 trading partners and also analyse the robustness of model.

In general, our models suggest that the quality of institutions contributes positively to Indonesian export performance in all commodities, but with different roles and magnitudes. Firstly, in raw material and capital goods export, trading partners' institutions play significant roles while domestic institutions do not. Secondly, on the other hand, on two products that are relevant to the global value chain for the case of Indonesian intermediate and consumer goods, both domestic institutions and trading partners' institutions significantly contribute to Indonesian export performance. In addition, although both domestic institutions and trading partners institutions play significant roles in the two commodities, the magnitudes are somewhat different. That is, four aspects of domestic institutions affect more relatively with respect to trading partners' institutions as indicated by their coefficients. Thirdly, higher coefficients of four domestic institutions have aspects that are relative to other variables, which might indicate that domestic institutions play dominant roles in Indonesian bilateral trade of the two commodities.

The main conclusion on the tariff variable, which is a proxy to evaluate the performance of Indonesian export from its free trade cooperation, are the following. Firstly, our results seem to suggest that tariff reduction is less significant to its export performance on raw material and capital goods. Secondly, on the other hand, import tariff reductions by trading partners significantly increase Indonesian export on intermediate and consumer goods. Despite its significances, however, our models suggest that tariff reductions are still lower than the institutional quality factor in explaining Indonesian export performance in the two commodities that are relevant to Indonesia involvement potentials in the global value chain. These results, again, highlight the importance of domestic institutional quality in explaining the trade performance of intermediate and consumer goods. 


\section{References}

Abidin, I.S.Z., Bakar, N.A., Sahlan, R., 2013. The Determinants of Exports between Malaysia and the OIC Member Countries: A Gravity Model Approach. Procedia Economics and Finance 5, 12-19. https://doi.org/10.1016/S2212-5671(13)00004-X

Adams, F.G., Gangnes, B., Shachmurove, Y., 2006. Why is China so Competitive? Measuring and Explaining China's Competitiveness. World Economy 29, 95-122. https://doi.org/10.1111/j.1467-9701.2006.00773.x

Álvarez, I.C., Barbero, J., Rodríguez-Pose, A., Zofío, J.L., 2018. Does Institutional Quality Matter for Trade? Institutional Conditions in a Sectoral Trade Framework. World Development 103, 72-87. https://doi.org/10.1016/j.worlddev.2017.10.010

Anderson, J.E., Marcouiller, D., 2002. Insecurity and the Pattern of Trade: An Empirical Investigation. Review of Economics and Statistics 84, 342-352. https://doi.org/10.1162/003465302317411587

Angkinand, A.P., Chiu, E.M.P., 2011. Will institutional reform enhance bilateral trade flows? Analyses from different reform aspects. Journal of Economic Policy Reform 14, 243258. https://doi.org/10.1080/17487870.2011.576485

Athukorala, P.-C., 2006. Post-crisis export performance: The Indonesian experience in regional perspective. Bulletin of Indonesian Economic Studies 42, 177-211. https://doi.org/10.1080/00074910600873658

Babecká Kucharčuková, O., Babecký, J., Raiser, M., 2012. Gravity Approach for Modelling International Trade in South-Eastern Europe and the Commonwealth of Independent States: The Role of Geography, Policy and Institutions. Open Econ Rev 23, 277-301. https://doi.org/10.1007/s11079-010-9187-8

Berkowitz, D., Moenius, J., Pistor, K., 2006. Trade, Law, and Product Complexity. Review of Economics and Statistics 88, 363-373. https://doi.org/10.1162/rest.88.2.363

Borrmann, A., Busse, M., Neuhaus, S., 2006. Institutional Quality and the Gains from Trade. Kyklos 59, 345-368. https://doi.org/10.1111/j.1467-6435.2006.00336.x

Clarida, R.H., Findlay, R., 1992. Government, Trade, and Comparative Advantage. The American Economic Review 82, 122-127.

Costinot, A., 2009. On the origins of comparative advantage. Journal of International Economics 77, 255-264. https://doi.org/10.1016/j.jinteco.2009.01.007

Dollar, D., Kidder, M., 2017. Institutional quality and participation in global value chains, in: Global Value Chain Development Report 2017 : Measuring and Analyzing the Impact of GVCs on Economic Development. World Bank, pp. 161-173.

Dollar, D., Kraay, A., 2003. Institutions, trade, and growth. Journal of Monetary Economics 50, 133-162. https://doi.org/10.1016/S0304-3932(02)00206-4

Doyle, E., Martinez-Zarzoso, I., 2011. Productivity, Trade, and Institutional Quality: A Panel Analysis. Southern Economic Journal 77, 726-752. https://doi.org/10.4284/sej.2011.77.3.726

Essaji, A., Fujiwara, K., 2012. Contracting institutions and product quality. Journal of Comparative Economics 40, 269-278. https://doi.org/10.1016/j.jce.2011.07.005

Faruq, H.A., 2011. How institutions affect export quality. Economic Systems 35, 586-606. https://doi.org/10.1016/j.ecosys.2011.05.001

Francois, J., Manchin, M., 2013. Institutions, Infrastructure, and Trade. World Development 46, 165-175. https://doi.org/10.1016/j.worlddev.2013.02.009 
Fugazza, M., 2005. Developing Countries in International Trade. United Nations Conference on Trade and Development.

Funke, M., Ruhwedel, R., 2001. Export variety and export performance: empirical evidence from East Asia. Journal of Asian Economics 12, 493-505. https://doi.org/10.1016/S1049-0078(01)00100-2

Gani, A., Prasad, B.C., 2006. Institutional Quality and Trade in Pacific Island Countries. AsiaPacific Research and Training Network on Trade Working Paper Series 20.

Gómez-Herrera, E., 2013. Comparing alternative methods to estimate gravity models of bilateral trade. Empir Econ 44, 1087-1111. https://doi.org/10.1007/s00181-0120576-2

Greaney, T.M., Kiyota, K., 2020. The gravity model and trade in intermediate inputs. World Econ 43, 2034-2049. https://doi.org/10.1111/twec.12947

Islam, M.N., 1998. Export Expansion and Economic Growth: Testing for Cointegration and Causality. Applied Economics 30, 415-425. https://doi.org/10.1080/000368498325930

Isnawangsih, A., Lu, Y., 2018. Diversifying Merchandise Exports, in: Breuer, L.E., Guajardo, J., Kinda, T. (Eds.), Realizing Indonesia's Economic Potential. International Monetary Fund, Washington, DC, pp. 187-209.

Iwanow, T., Kirkpatrick, C., 2007. Trade facilitation, regulatory quality and export performance. J. Int. Dev. 19, 735-753. https://doi.org/10.1002/jid.1399

Jansen, M., Nordås, H.K., 2004. Institutions, Trade Policy and Trade Flows. SSRN Electronic Journal. https://doi.org/10.2139/ssrn.923544

Jongwanich, J., 2010. Determinants of Export Performance in East and Southeast Asia. World Economy 33, 20-41. https://doi.org/10.1111/j.1467-9701.2009.01184.x

Kaufmann, D., Kraay, A., Mastruzzi, M., 2010. The Worldwide Governance Indicators: Methodology and Analytical Issues. World Bank Policy Research Working Paper 5430.

Keane, J., 2017. Effectively Governing Global Value Chains: The Institutional Interface | READ online, in: Future Fragmentation Processes: Effectively Engaging with the Ascendancy of Global Value Chain. Commonwealth Secretariat, London, p. 15.

Khandelwal, A., 2010. The Long and Short (of) Quality Ladders. The Review of Economic Studies 77, 1450-1476.

Kindleberger, C.P., 1978. Government and International Trade. Essays in International Finance-Princeton University 36.

Krenz, A., 2016. Do Political Institutions Influence International Trade? Measurement of Institutions and the Long-Run Effects. SSRN Journal. https://doi.org/10.2139/ssrn.2732549

Levchenko, A.A., 2007. Institutional Quality and International Trade. The Review of Economic Studies 74, 791-819. https://doi.org/10.1111/j.1467-937X.2007.00435.x

Linders, G.-J.M., 2004. The Effect of Domestic Institutions on International Trade Flows: A sectoral analysis. 44th Congress of the European Regional Science Association: "Regions and Fiscal Federalism", 25th - 29th August 2004, Porto, Portugal, European Regional Science Association (ERSA), Louvain-la-Neuve.

Martínez-Zarzoso, I., 2013. The log of gravity revisited. Applied Economics 45, 311-327. https://doi.org/10.1080/00036846.2011.599786 
Méon, P.-G., Sekkat, K., 2008. Institutional Quality and Trade: Which Institutions? Which Trade? Economic Inquiry 46, 227-240. https://doi.org/10.1111/j.14657295.2007.00064.x

Molnar, M., Lesher, M., 2008. Recovery and Beyond: Enhancing Competitiveness to Realise Indonesia's Trade Potential (OECD Trade Policy Papers No. 82), OECD Trade Policy Papers. https://doi.org/10.1787/227205773037

Myint, H., 1979. Exports and Economic Development of Less Developed Countries, in: Adelman, I. (Ed.), Economic Growth and Resources. Palgrave Macmillan UK, London, pp. 102-120. https://doi.org/10.1007/978-1-349-16229-1_10

North, D.C., 1991. Institutions. Journal of Economic Perspectives 5, 97-112. https://doi.org/10.1257/jep.5.1.97

Nunn, N., 2007. Relationship-Specificity, Incomplete Contracts, and the Pattern of Trade. The Quarterly Journal of Economics 122, 569-600. https://doi.org/10.1162/qjec.122.2.569

Nunn, N., Trefler, D., 2014. Domestic Institutions as a Source of Comparative Advantage, in: Handbook of International Economics. Elsevier, pp. 263-315. https://doi.org/10.1016/B978-0-444-54314-1.00005-7

Ohlin, B., 1979. Some Insufficiencies in the Theories of International Economic Relations. Essays in International Finance-Princeton University 28.

Palley, T.I., 2012. The Rise and Fall of Export-led Growth. Investigación Económica 71, 141161. http://dx.doi.org/10.22201/fe.01851667p.2012.280.37339

Parrinello, S., 2002. The "institutional factor" in the theory of international trade: new vs. old trade theories, in: Is There Progress in Economics? Edward Elgar Publishing, p. 2403. https://doi.org/10.4337/9781843765622.00028

Ranjan, P., Lee, J.Y., 2007. Contract Enforcement and International Trade. Economics \& Politics 19, 191-218. https://doi.org/10.1111/j.1468-0343.2007.00308.x

Santos Silva, J.M.C., Tenreyro, S., 2006. The Log of Gravity. Review of Economics and Statistics 88, 641-658. https://doi.org/10.1162/rest.88.4.641

Sheng, L., Yang, D.T., 2016. Expanding export variety: The role of institutional reforms in developing countries. Journal of Development Economics 118, 45-58. https://doi.org/10.1016/j.jdeveco.2015.08.009

Soeng, R., Cuyvers, L., 2018. Domestic institutions and export performance: Evidence for Cambodia. The Journal of International Trade \& Economic Development 27, 389408. https://doi.org/10.1080/09638199.2017.1386230

Soesastro, H., Basri, M.C., 2005. The Political Economy of Trade Policy in Indonesia. ASEAN Economic Bulletin 22, 3-18.

Souva, M., Smith, D.L., Rowan, S., 2008. Promoting Trade: The Importance of Market Protecting Institutions. The Journal of Politics 70, 383-392. https://doi.org/10.1017/S0022381608080377

Sy, B., Villejo, S.J., Lacaza, R., 2020. An Analysis of the Impact of ASEAN's Logistics Performance on Trade Flows Using Linear and Non-linear methods in an Augmented Gravity Model, 5th ed. Bundesvereinigung Logistik (BVL) e.V., DE.

Trung, N.X., Hung, N.D., Hien, N.T., 2018. Exploiting the Trade Potential from Integration: Analysing the Impact of Free Trade Agreements between ASEAN and India and China. China Report 54, 442-466. https://doi.org/10.1177/0009445518795999

Wengel, J. ter, Rodriguez, E., 2006. SME Export Performance in Indonesia after the Crisis. Small Business Economics 26, 25-37. https://doi.org/10.1007/s11187-004-6491-y 
Appendix 1: List of Indonesia trading partners included in the study
1. Australia
10. Korea, Rep.
2. Bangladesh
11. Malaysia
3. China
12. Netherlands
4. Germany
13. Pakistan
5. Spain
14. Philippines
6. Hong Kong SAR, China
15. Singapore
7. India
16. Thailand
8. Italy
17. United States
9. Japan
18. Vietnam

\section{Declarations}

Availability of data and materials

The datasets used and analysed during the current study are available from the corresponding author on request

\section{Competing interests}

The authors declare that they have no competing interests

\section{Funding}

No funding is used

\section{Authors contributions}

$A B$ was a major contributor to the article, provided research idea and initial research framework, performed data gathering, estimation of the model and analysis. RI contributed to research framework and interpretation. BB supervised variables and data cleaning process, estimation process as well as gave partial economic analysis to econometric results. TA contributed to research framework and modelling process. All authors read and approved the final manuscript.

\section{Acknowledgements}

This article is part of $A B^{\prime}$ 's doctorate thesis, and the three other authors are the supervisors. The authors wish to thank Dr Matthew Copley for his proofreading and English editing. 